\title{
15
}

\section{Characterisation and sourcing of archaeological adzes and flakes from Fiji}

\author{
Barry Fankhauser \\ Department of Archaeology and Natural History, The Australian National University \\ Geoffrey Clark \\ Department of Archaeology and Natural History, The Australian National University \\ Atholl Anderson \\ Department of Archaeology and Natural History, The Australian National University
}

\section{Introduction}

This chapter focuses on the characterisation and sourcing of lithic artefacts (adzes and flakes) found in excavations conducted in 1996 and 1997 on Beqa Island, Mago Island and Viti Levu. Although the primary focus is on basalt because of accumulated knowledge, other rock types are represented due to the diversity of lithic materials found in Fiji in contrast to oceanic basalts in the island groups of Polynesia. Lithic material found in the Fijian Islands could be from the island on which it was found, from within the archipelago, or imported from another island group, especially from Samoa (Best 1984; Best et al. 1992; Weisler 1993a). Determination of the provenance of raw materials found during excavation of a site can be valuable in providing information on contacts between that location and others. Provenance is defined here as the material's place of origin, i.e. the geological source (see Weisler 1993c:62).

Most studies have focused on basalt, which was the most widely distributed commodity in prehistoric Polynesia to the east of Fiji, and therefore has the potential to contribute most to the understanding of prehistoric trade and social interaction. In addition to Samoa, basalt sourcing studies have been undertaken in several island groups of Polynesia, including the Cook Islands 
(Walter 1990; Weisler 1994; Walter and Sheppard 1996; Sheppard et al. 1997), Pitcairn and Mangareva (Weisler 1993b, 1994, 1995, 1996a, 1996b) and Hawaii (Cleghorn et al. 1985; Weisler 1990a, 1990b, 1990c). Determining the source of an object depends on regional geological knowledge, i.e. the macroscopic, petrographic and geochemical attributes of source material. Basalt sources in much of Polynesia have been extensively studied and chemically analysed. This is not the case for Fiji. Fijian lithic sources have not been geochemically characterised except for some analyses conducted by Best (1984). Fiji is more petrologically diverse given its location to the west of the Andesite Line, which separates Samoa and the rest of Polynesia (alkali and tholeitic oceanic basalts) from the andesite-plutonic rocks of Tonga and Fiji (Dickinson and Shutler 1979; Sinton et al. 1985). The results of a second project investigating the chemical composition of siliceous artefacts are presented in the Appendix.

\section{Geochemical characterisation of adze rocks}

Weisler (1993c) has given a summary of references which deal with different types of analysis for basalt sourcing in Polynesia. These include macroscopic descriptions of adzes and polished flakes (R. Green 1974:141; Kirch 1988:192), thin-section analysis (Buist 1969; Emory 1975; Kirch 1975; Best 1984; T. Green 1984; Cleghorn et al. 1985; White 1987; Weisler 1990b; Withrow 1990, 1991), and geochemical analysis of adze material (Best 1984; Walter 1990; Best et al. 1992; Weisler 1989, 1990b, 1993a). Additional references for geochemical analysis include: Walter and Sheppard 1996; Weisler and Kirch 1996; Weisler and Woodhead 1995; Weisler et al. 1994; and several articles in a monograph edited by Weisler (1997a).

Macroscopic observations can at times be useful, but given similar colour, mineralogy and weathering effects of lithic materials, conclusions based on these observations should be approached with caution. Thin-section descriptions have some of the limitations above, but can provide useful data to discriminate sources in certain circumstances (Best 1984; Cleghorn et al. 1985; White 1987). Either of the above techniques should be combined with geochemical techniques to be most effective in discriminating provenance. Weisler (1993c:68) gives the following reasons for the power of geochemical analysis as an analytical tool: (1) its results are reproducible; (2) instrument specifications and operating conditions can be reported in full; (3) identification of chemical components is not subject to human error; (4) elemental abundances can be determined with accuracy and precision parameters noted; (5) use of standards facilitates inter-laboratory comparisons of databases; and (6) the analytical sample taken to analyse bulk chemical constituents more closely represents the whole specimen, in contrast to a twodimensional thin-section.

Major and minor element compositions of basalts in the Pacific have been found by researchers doing sourcing studies to be similar over wide areas (Weisler and Woodhead 1995; Sinton and Sinoto 1997), making assignment to a specific source difficult. Assignments to sources from petrographic examination can also be problematic because of similarities in mineralogy (Weisler and Kirch 1996). Also, quarried stone weathers over time and at different rates depending on ambient conditions (Best et al. 1992). Weathering not only affects the petrography but also the chemical make-up (the elemental signature) of the stone. However, the combination of elemental analysis and petrological analysis is more likely to identify identical source material.

Ideally, for sourcing of individual artefacts using geochemical data, it is necessary for all potential sources to have been described and analysed (Wilson 1978; Rapp 1985; Weisler and Sinton 1997:177). This ideal probably is never realised and certainly in the case of basalt in the Pacific, many prehistoric quarries have not been characterised (Weisler and Sinton 1997). 
However, several sourcing studies have been successful and have demonstrated intra-archipelago as well as inter-archipelago transfer of basalt. Island quarries which have been most studied are those of Hawaii and Samoa.

In this research, 10 major and minor elements were analysed using energy dispersive X-Ray analysis (EDXA). The advantages of this method over, for example, X-Ray Fluorescence (XRF) are the ease of sample preparation and presentation to the instrument and a much smaller sample size. However, EDXA is not as accurate as XRF. Analytical accuracy is about $6 \%$ for a $10 \mathrm{wt} \%$ concentration of an element, and improves at higher concentrations. The limit of detection is about 0.1 wt\% (Williams 1987; Goodhew and Humphreys 1988). Sheppard et al. (1997:Table 6.2) present accuracy and precision information for XRF data. It is possible using XRF to analyse whole specimens, but with less accuracy than prepared samples (Weisler 1993a).

Nineteen trace elements were analysed using inductively coupled plasma-mass spectrometry (ICP-MS). ICP-MS has detection limits of parts per billion for most of the elements in the periodic table and requires only small sample sizes of ca. $100 \mathrm{mg}$ (Jarvis et al. 1992). This is a much smaller detection limit and sample size than required for XRF. Historically, most analytical work for sourcing in the Pacific has been done using XRF with its limitations, but ICP-MS will probably become more popular in the future. XRF performs best analysing certain elements and this characteristic has often defined the element suite used to characterise lithic sources.

Weisler and Sinton (1997:179) indicate the elements least affected by the combination of real, local source variability and analytical uncertainty are $\mathrm{Si}$, Ti, $\mathrm{Al}, \mathrm{Fe}, \mathrm{Mg}, \mathrm{Ca}, \mathrm{K}, \mathrm{V}, \mathrm{Sr}, \mathrm{Y}, \mathrm{Zr}$ and Ba. Best (1984) and Best et al. (1992) indicate the best discriminators of the major/minor elements are $\mathrm{SiO}_{2}, \mathrm{TiO}_{2}$ and $\mathrm{P}_{2} \mathrm{O}_{5}$ and they plotted these values to show relationships between sources. For Weisler and Sinton (1997), the most efficient discriminators are $\mathrm{SiO}_{2}, \mathrm{TiO}_{2}$ and $\mathrm{K}_{2} \mathrm{O}$.

Best's (1984) analyses of adzes and rocks from southern Lau were chosen for comparison with Fiji lithics. These samples were chosen because they would be most likely to furnish information on the possible origins of the adzes and flakes analysed in the present project. Best divided the rock types into five main groups: basalts, andesites, tuffs, all other igneous rocks, and sedimentary rocks. He further divided the basalts into six subgroups:

1. Those with a distinctive glassy texture;

2. Those containing celadonite/biotite;

3. Those containing olivine;

4. Limburgite - oceanic basalt;

5. Leucite - feldspathoidal basalt; and

6. All others.

Best found that the preference for, or presence of, various rock types changed considerably through time. Eight of the Lauan adzes and a Taveuni specimen grouped with two Samoan sources. For Best (1984:406), the most interesting aspect of the island's adze material was that so much of it came from so far away.

In addition to Best's samples, a database of basalt analyses from several researchers was compiled. Sample analyses were chosen from this database for comparison with the chemical analyses of excavated flakes and adzes. Sinton and Sinoto (1997) have constructed a database of basalt analyses from Polynesia containing chemical analyses of 280 individual samples from 36 quarries. 
Cluster analysis was used to find out which analyses in a data set were similar. Cluster analysis is a method for describing the similarities among objects in a sample (Romesburg 1984). Cluster analysis results in a diagram called a dendrogram that shows the hierarchy of similarities among all pairs of objects. Other methods of analysing the data were tried, such as plotting ratios of elements or oxides (see, for example, Best et al. 1992) and principal components analysis. Results were similar to results from other methods of data analysis, but dendrograms are more clearly visualised, especially when there are many data points. The cophenetic correlation coefficient is an index that tells us how much the clustering method distorts the information in its input in order to produce its output or the dendrogram. Values for the cophenetic correlation of around 0.8 indicate the distortion is not great. Cophenetic correlations were calculated in this study and varied from 0.85 to 0.92 .

Some samples from the Fiji excavations were closely linked with Best's (1984) samples. In addition, some of the 25 samples were closely linked with each other through both major oxide and minor element clustering, as well as being similar petrologically. No samples were similar to those from Samoa, but this could be expected given the morphology of the analysed artefacts.

\section{Adze samples: Materials and methods}

Various lithic flakes and adze fragments were provided from excavations conducted in 1996 and 1997 in Fiji, on Beqa Island, Viti Levu and Mago Island. Most of the samples were basalt, but other rock types were represented. Although the sample size was limited, 25 artefacts which were obviously flakes and adze fragments were sampled.

After visually inspecting, weighing and measuring the artefacts, small pieces were cut from each piece using a diamond saw. Samples for energy dispersive X-Ray analysis (EDXA) weighed approximately $50 \mathrm{mg}$ and those for inductively coupled plasma spectroscopy-mass spectrometry (ICP-MS) ranged from $250 \mathrm{mg}$ to $400 \mathrm{mg}$.

The samples for ICP-MS were polished on 240 grit wet emery paper to remove possible contamination from the diamond saw blade. The samples were then washed and put into an ultrasonic bath to remove any adhering particles. Samples were weighed and put into separate micro-centrifuge tubes for posting to the Advanced Analytical Centre at James Cook University for trace-element analysis. Samples were whole pieces and were not pulverised in order to avoid contamination from any grinding apparatus.

The pieces for EDXA were washed and dried. They were then mounted in a jig holding 26 samples, especially made for the mount available for the electron microscope. The samples were epoxied into holes in the jig. This allowed them to be polished flat for analysis. Polishing was done using 240, 400 and 600 grit wet emery cloth, followed by polishing compound (cerium oxide) on glass. The mounted samples were washed in detergent in an ultrasonic bath. The polished samples were viewed with a microscope at 20x magnification.

Samples were dried at $120^{\circ} \mathrm{C}$ for 17 hours and were weighed before and after heating to give a loss on drying (LOD) expressed as a percentage. Dried samples were then fired in a muffle furnace at $500^{\circ} \mathrm{C}$ for four hours. The percentage mass loss on ignition (LOI) was determined.

\section{Energy dispersive X-Ray analysis}

The SEM-EDXA instrument is located in the Electron Microscopy Laboratory at the Research School of Biological Sciences, ANU. The instrument used was a JEOL JSM-6400 scanning electron microscope (SEM), fitted with an Oxford $138 \mathrm{eV} \mathrm{SATW} 10 \mathrm{~mm}^{2}$ detector. The analysis system was an Oxford ISIS using SEMQUANT. Samples were coated with carbon before analysis. Analyses were done using $15 \mathrm{keV}$ at $1 \mathrm{nA}$ for 200 seconds live time. Most analyses 
were done at 150-180x magnification, although this ranged from 150x to 400x depending on the homogeneity of the sample. Lower magnifications were used on non-homogeneous samples to 'average' the surface. Results were in element percent and the oxides were calculated stoichiometrically.

\section{Inductively coupled plasma spectroscopy with mass spectrometry}

The sample preparation at James Cook University was done using a method from Jarvis et al. (1992:Chapter 7). The solid samples along with a reference standard (Hawaiian basalt: BHVO1) were prepared by digesting with a mixture (4:1) of concentrated hydrofluoric acid and concentrated nitric acid, and finally taken up in 2\% nitric acid. The ICPMS (Model 'Ultramass') was manufactured by Varian Australia. The instrument parameters are given in Table 77. Phosphorus was analysed separately using ICP-atomic emission spectroscopy (ICP-AES).

Table 77. Varian ICP-MS instrument settings for trace-element analysis.

\begin{tabular}{ll}
\hline Instrument Parameters & Segmented Scan Mode \\
\hline Plasma Flow $15.0 \mathrm{~L} / \mathrm{min}$ & \\
Auxillary Flow $1.50 \mathrm{~L} / \mathrm{min}$ & \\
Nebuliser Flow $1.07 \mathrm{~L} / \mathrm{min}$ & \\
Sampling Depth $5.0 \mathrm{~mm}$ & \\
Forward Power $1.2 \mathrm{~kW}$ & \\
Sample Pump Rate $25 \mathrm{rpm}$ & \\
Extraction Lens $-600 \mathrm{~V}$ & Reading Space $0.025 \mathrm{AMU}$ \\
First Lens $\quad-360 \mathrm{~V}$ & Points per Peak 3 \\
Second Lens $-13.60 \mathrm{~V}$ & Scans Replicate 5 \\
Third Lens $\quad 0.60 \mathrm{~V}$ & No. of Replicates 5 \\
Fourth Lens $-10 \mathrm{~V}$ & Dwell Time $1000 \mathrm{mS}$ \\
Photon Stop $-15.60 \mathrm{~V}$ & Sample Delay 40 \\
Entrance Plate $0 \mathrm{~V}$ & Stabilisation Time 15 \\
Exit Plate $\quad 0 \mathrm{~V}$ & Rinse Time 70 \\
\hline
\end{tabular}

\section{Cluster analysis}

The agglomerative hierarchical clustering algorithms available in the statistical system NCSS 6.0.1 were used to build a cluster hierarchy displayed as a tree diagram or dendrogram. The group average (unweighted pair-group) method was used.

\section{Comparison samples}

A database of basalt chemical analyses was constructed which incorporated results from several researchers. Analyses were either typed or scanned from journal articles and especially from a monograph edited by Weisler (1997a) which contains values from most basalt sourcing studies. Samples were selected from the database for cluster analysis to provide a comparison with the excavated flakes and adzes.

\section{Adze samples: Results and discussion}

Description of samples

The samples analysed in this project and site details are given in Table 78 (see also Table 79). The adzes and flakes listed turned out to be not all basalts. This would be expected for lithics in 
Table 78. Description of analysed archaeological samples from Fiji.

\begin{tabular}{|c|c|c|c|c|c|c|}
\hline Lab No. & Sample Context & Sample Description & Dimensions & Mass (g) & LOD \% & LOI \% \\
\hline & & & Length $\mathrm{x}$ Width $(\mathrm{cm})$ & & & \\
\hline $\mathrm{F} 1$ & Beqa Is, Kulu Bay, C10, $90-100 \mathrm{~cm}$ & Dark grey, fine-grained adze & $5.5 \times 2.8$ & 36.72 & 0.06 & 0.17 \\
\hline F2 & Beqa Is, Kulu Bay, C10, $90-100 \mathrm{~cm}$ & Black, fine-grained adze flake & $2.4 \times 1.5$ & 1.44 & 0.00 & 0.10 \\
\hline F3 & Beqa Is, Kulu Bay, $c 10,90-100 \mathrm{~cm}$ & Dark grey, fine-grained adze flake & $2.9 \times 1.8$ & 2.19 & 0.59 & 0.30 \\
\hline F4 & Beqa Is, Kulu Bay, C11, 10-20 cm & Grey, fine-grained adze flake & $2.3 \times 1.0$ & 0.81 & 0.58 & 0.88 \\
\hline F5 & Beqa Is, Kulu Bay, C10, 30-50 cm & Grey, fine-grained adze flake & $5.6 \times 4.5$ & 32.37 & 0.42 & 0.60 \\
\hline F6 & Beqa Is, Kulu Bay, C10, 30-50 cm & Greenish, fine-grained adze flake & $4.3 \times 4.2$ & 13.99 & 0.06 & 0.22 \\
\hline F7 & Beqa Is, Kulu Bay, $C 10,30-50 \mathrm{~cm}$ & Greenish, fine-grained adze flake & $2.2 \times 1.9$ & 1.70 & 0.08 & 0.31 \\
\hline F8 & Beqa Is, Ugaga Is, L9: $40 \mathrm{~cm}$ & Grey, very fine-grained adze & $6.5 \times 2.3$ & 31.29 & 0.38 & 0.51 \\
\hline F9 & Beqa Is, Ugaga Is, D8: $30-40 \mathrm{~cm}$ & Grey, fine-grained adze flake & $2.7 \times 1.3$ & 1.69 & 0.28 & 0.09 \\
\hline F10 & Natunuku, Trench 3, Level 1: 20-30 cm & Dark grey, fine-grained, adze flake & $8.5 \times 7.4$ & 232.34 & 0.04 & 0.00 \\
\hline $\mathrm{F} 11$ & Mago Is, Votua TP1: $20-30 \mathrm{~cm}$ & Thin, fine-grained, dark grey adze flake & $2.8 \times 1.2$ & 0.83 & 0.04 & 0.24 \\
\hline $\mathrm{F} 12$ & Natunuku, Trench 3, Level 1: 10-20 cm & $\begin{array}{l}\text { Dark grey and brown, fine-grained adze tip. } \\
\text { Appears similar to F10 }\end{array}$ & $5.0 \times 6.1$ & 90.91 & 0.54 & 0.28 \\
\hline F13 & Natunuku, TP 2-4, Level 1: 10-20 cm & Greenish, fine-grained adze flake & $6.4 \times 3.8$ & 27.50 & 0.17 & 0.27 \\
\hline F14 & Natunuku, TP 2, Level 1: 10-20 cm & Grey, fine-grained adze flake & $3.4 \times 2.1$ & 6.90 & 0.09 & 0.24 \\
\hline $\mathrm{F} 15$ & Natunuku, TP 2, Level 1: 10-20 cm & Grey, fine-grained adze flake & $3.3 \times 1.7$ & 3.29 & 0.17 & 0.21 \\
\hline F16 & Natunuku, Trench 3, B5, Layer 2 & Greenish-grey, fine-grained adze (?) flake & $6.7 \times 3.4$ & 49.32 & 0.14 & 0.29 \\
\hline F17 & Beqa Is, Kulu Bay, C10: $50-70 \mathrm{~cm}$ & Black, fine-grained adze flake & $4.5 \times 2.0$ & 4.89 & 0.11 & 0.14 \\
\hline F18 & Beqa Is, Kulu Bay, C11: 20-30 cm & Grey, very fine-grained adze flake & $3.7 \times 1.2$ & 2.11 & 0.49 & 0.61 \\
\hline F19 & Beqa Is, Kulu Bay, C11: 30-40 cm & Grey, fine-grained core with flake scars & $2.0 \times 1.9$ & 4.81 & 0.13 & 0.10 \\
\hline $\mathrm{F} 20$ & Beqa Is, Kulu Bay, $C 11: 30-40 \mathrm{~cm}$ & Grey, fine-grained adze flake & $2.5 \times 1.7$ & 3.45 & 0.04 & 0.00 \\
\hline$F 21$ & Beqa Is, Kulu Bay, C11: $90-100 \mathrm{~cm}$ & Grey, fine-grained adze flake & $2.3 \times 1.6$ & 1.85 & 0.08 & 0.08 \\
\hline$F 22$ & Beqa Is, Kulu Bay, C11: 110-120 cm & Grey, fine-grained thin adze flake & $2.6 \times 1.7$ & 1.46 & 0.68 & 0.59 \\
\hline$F 23$ & Beqa Is, Kulu Bay, C11: 110-120 cm & Grey, very fine-grained thin adze flake & $2.0 \times 0.7$ & 0.30 & nd & nd \\
\hline$F 24$ & Beqa Is, Ugaga Is, N10: $40 \mathrm{~cm}$ & Grey, fine-grained adze flake & $5.2 \times 2.8$ & 75.74 & 0.07 & 0.11 \\
\hline $\mathrm{F} 25$ & Beqa Is, Kulu Bay, C11: $30-40 \mathrm{~cm}$ & $\begin{array}{l}\text { Grey, ?adze flake with black and white } \\
\text { crystals }\end{array}$ & $2.8 \times 1.3$ & 3.07 & 0.74 & 0.39 \\
\hline
\end{tabular}

$L O D=$ loss on drying at $120^{\circ} \mathrm{C} ; \mathrm{LO}=$ loss on ignition at $500^{\circ} \mathrm{C} ; \mathrm{nd}=$ not determined

Fiji (Best 1984), where several rock types are represented. The samples which visually appeared to be basalt are numbers: F5-F8, F15, and F17-F22. The green and black crystals would likely be olivine and biotite (or iron oxide), respectively. Brown crystals could be weathered biotite or celadonite (Best 1984). Other rock types could not be identified because this is an area for a specialist and no thin-sections were made. Samples which by eye appeared similar and could be from the same sources are groups: F5, F6, F7; F13, F16; F17, F20; F24, F25; and possibly F9, F11. 
Some samples appeared quite weathered, especially samples F10, F12, F15, F20 and F25. The greenish appearance of some flakes (Table 78) might be due to weathering. The descriptions presented in Table 79 are more reliable because the samples had a fresh polished surface. Texture and crystals could easily be seen and compared.

The loss on ignition (LOI) values are all less than one (Table 78). Best et al. (1992:53) indicate that if a sample is badly weathered and has an LOI $>1 \%$, it plots away from the main group. They therefore omitted such samples from plots of chemical analyses.

\section{Database samples}

The publications which provided major/minor element oxide data are given in Table 80. The number of samples incorporated into the database is also given. Most authors have included all of the relevant oxides and this is a consideration in the selection of samples for comparison. The number of samples actually available for comparison is much less than the total number indicated. This is because of the repetition involved when researchers incorporate sample values presented in the literature for their own sourcing comparisons.

Table 79. Description of lithic samples as viewed in mounting plate at 20x magnification.

\begin{tabular}{|c|c|c|}
\hline Lab. No. & Description & Homogeneous? \\
\hline F1 & Black, fine grained & Yes \\
\hline F2 & Black, very fine grained & Yes \\
\hline F3 & Dark grey, some white phenocrysts & Fairly \\
\hline F4 & Brown, fine grained & Yes \\
\hline F5 & Grey, some white and brown inclusions & Yes \\
\hline F6 & Light grey, small black inclusions & Yes \\
\hline F7 & Light grey, light green (olivine?) and black crystals & Fairly \\
\hline F8 & Grey, fine grained & Yes \\
\hline F9 & Dark grey, small black and brown crystals & Fairly \\
\hline F10 & Grey to black, large white and black phenocrysts & No \\
\hline F11 & Black, very fine grained & Yes \\
\hline $\mathrm{F} 12$ & Grey, large white crystals & No \\
\hline F13 & Grey, very small black crystals & Yes \\
\hline F14 & Dark grey, small black crystals & Yes \\
\hline F15 & Black, large white crystals & No \\
\hline F16 & Brown, fine grained, appearance of silt stone & Yes \\
\hline F17 & Brown to black, coarse grained, white and brown crystals & Fairly \\
\hline F18 & Grey, fine grained, some small black crystals & Yes \\
\hline F19 & Black, very fine grained & Yes \\
\hline $\mathrm{F} 20$ & Black, course grained, white crystals, similar to F15 & No \\
\hline$F 21$ & Dark grey, fine grained with few very small white crystals & Fairly \\
\hline$F 22$ & Dark grey, fine grained, very small black flecks & Yes \\
\hline$F 23$ & Grey, very fine grained & Yes \\
\hline $\mathrm{F} 24$ & Black, very fine grained & Yes \\
\hline $\mathrm{F} 25$ & Very weathered, large crystals, similar to F12 & No \\
\hline
\end{tabular}


Table 80. Publications containing lithic source and artefact major/minor element oxide data.

\begin{tabular}{|c|c|c|c|c|c|c|c|c|c|c|c|c|}
\hline : & 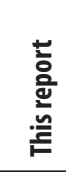 & 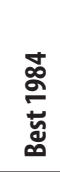 & 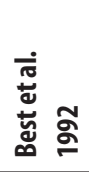 & 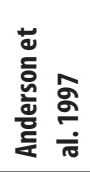 & 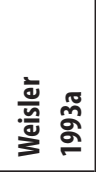 & 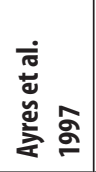 & 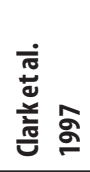 & 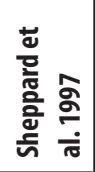 & 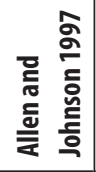 & 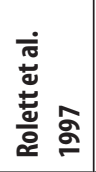 & 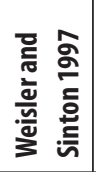 & 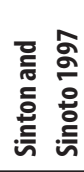 \\
\hline $\mathrm{N}$ & 25 & 44 & 163 & 10 & 3 & 7 & 37 & 97 & 20 & 20 & 9 & 33 \\
\hline $\mathrm{SiO}_{2}$ & & & & & & & & & & & & \\
\hline $\mathrm{TiO}_{2}$ & & & & & & & & & & & & \\
\hline $\mathrm{Al}_{2} \mathrm{O}_{3}$ & & & & & & & & & & & & \\
\hline $\mathrm{Fe}_{2} \mathrm{O}_{3}$ & & & & & & & & & & & & \\
\hline $\mathrm{Mn} 0$ & & & & & & & & & & & & \\
\hline $\mathrm{MgO}$ & & & & & & & & & & & & \\
\hline $\mathrm{CaO}$ & & & & & & & & & & & & \\
\hline $\mathrm{Na}_{2} \mathrm{O}$ & & & & & & & & & & & & \\
\hline $\mathrm{K}_{2} 0$ & & & & & & & & & & & & \\
\hline $\mathrm{P}_{2} \mathrm{O}_{5}$ & & & & & & & & & & & & \\
\hline
\end{tabular}

$\mathrm{N}=$ number of samples. Grey $=$ oxide included in study.

A large number of samples with trace-element analyses was available for incorporation into a database (Table 81). However, there was a problem of incompatibility between analyses performed in different and, at times the same, laboratories. Even though a large suite of elements was analysed in some studies (e.g. the present project; Best et al. 1992; Allen and Johnson 1997), results on several elements could not be used because only those elements common to all samples being considered could be used. For example, the element suite in this study contains 19 elements, but only 11 of these could be used for the clustering analysis.

\section{Major/minor element oxides}

The EDXA results are given in Table 82. The results for F1, F2, F3, F5, F14 and F16 are averages of duplicate analyses. The EDXA spectrum for sample F19 is presented in Figure 161. The phosphorus peak in this spectrum is not discernible by eye. Although $\mathrm{P}_{2} \mathrm{O}_{5}$ was analysed by EDXA, results from ICP-AES are included in this table because they are more accurate. EDXA values below ca. $1 \%$ are not reliable. The $\mathrm{P}_{2} \mathrm{O}_{5}$ values have been corrected to $\mathrm{BHVO}-1$ standard values. Total iron is presented as $\mathrm{Fe}_{2} \mathrm{O}_{3}$ although it would be better presented as ferrous iron $(\mathrm{FeO})$ because most of the iron in basalts is in this form (Wright 1971). However, most people doing sourcing research in the Pacific present $\mathrm{Fe}$ as $\mathrm{Fe}_{2} \mathrm{O}_{3} . \mathrm{SiO}_{2}$ values are generally higher and $\mathrm{TiO}_{2}$ values lower than those for oceanic island basalts (see Weisler and Sinton 1997:Table 10.5). There is a wide range of oxide concentrations and this may represent the diversity of rock types available locally. The sum of analyses varies from $94.78 \%$ to $104.70 \%$, with an average of $98.85 \%$. There appear to be no systematic errors in the values except for F19, which has an unusually high $\mathrm{TiO}_{2}$ value of $7.08 \%$ and an $\mathrm{MnO}$ value of $1.62 \%$. It appears that the EDXA beam sampled a Ti-rich mineral inclusion. The analysis of solid polished samples gives the most reliable results for EDXA, although non-homogeneous solid samples can present problems because of the small area analysed.

Some samples were powdered and analysed as a comparison to solid samples (Table 83). 
Table 81. Publications containing lithic source and artefact trace element data.

\begin{tabular}{|c|c|c|c|c|c|c|c|c|c|c|}
\hline 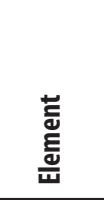 & 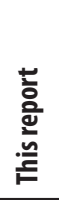 & 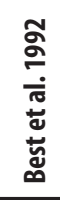 & 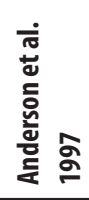 & 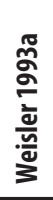 & 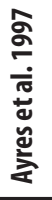 & 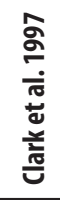 & 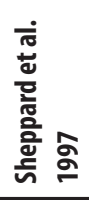 & 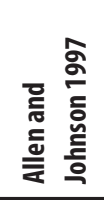 & 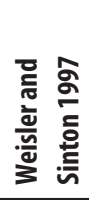 & 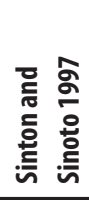 \\
\hline Number & 25 & 36 & 10 & 3 & 7 & 31 & 77 & 17 & 8 & 32 \\
\hline \multicolumn{11}{|l|}{ Sc } \\
\hline \multicolumn{11}{|l|}{$\mathrm{V}$} \\
\hline \multicolumn{11}{|l|}{$\mathrm{Cr}$} \\
\hline \multicolumn{11}{|l|}{$\mathrm{Ni}$} \\
\hline \multicolumn{11}{|l|}{$\mathrm{Cu}$} \\
\hline \multicolumn{11}{|l|}{$\mathrm{Zn}$} \\
\hline \multicolumn{11}{|l|}{$\mathrm{Rb}$} \\
\hline \multicolumn{11}{|l|}{$\mathrm{Sr}$} \\
\hline \multicolumn{11}{|l|}{$Y$} \\
\hline \multicolumn{11}{|l|}{$\mathrm{Zr}$} \\
\hline \multicolumn{11}{|l|}{$\mathrm{Nb}$} \\
\hline \multicolumn{11}{|l|}{ La } \\
\hline \multicolumn{11}{|l|}{ Ce } \\
\hline \multicolumn{11}{|l|}{$\mathrm{Nd}$} \\
\hline \multicolumn{11}{|l|}{$\mathrm{Sm}$} \\
\hline \multicolumn{11}{|l|}{ Eu } \\
\hline \multicolumn{11}{|l|}{ Dy } \\
\hline \multicolumn{11}{|l|}{$\mathrm{Er}$} \\
\hline \multicolumn{11}{|l|}{$\mathrm{Yb}$} \\
\hline \multicolumn{11}{|l|}{$\mathrm{Pb}$} \\
\hline \multicolumn{11}{|l|}{ Th } \\
\hline \multicolumn{11}{|l|}{ U } \\
\hline \multicolumn{11}{|l|}{$\mathrm{Ba}$} \\
\hline \multicolumn{11}{|l|}{$\mathrm{Ga}$} \\
\hline \multicolumn{11}{|l|}{$\mathrm{Fr}$} \\
\hline \multicolumn{11}{|l|}{$C_{0}$} \\
\hline \multicolumn{11}{|l|}{ As } \\
\hline $\mathrm{Tb}$ & & & & & & & & & & \\
\hline $\mathrm{Ra}$ & & & & & & & & & & \\
\hline Lu & & & & & & & & & & \\
\hline $\mathrm{Ta}$ & & & & & & & & & & \\
\hline Hf & & & & & & & & & & \\
\hline
\end{tabular}

Grey areas $=$ measured elements. 
Table 82. EDXA percentage concentrations for adzes and flakes from Fiji. Note $\mathrm{P}_{2} \mathrm{O}_{5}$ values determined by ICP-AES.

\begin{tabular}{|c|c|c|c|c|c|c|c|c|c|c|c|}
\hline Location & Lab. No. & $\mathrm{SiO}_{2}$ & $\mathrm{TiO}_{2}$ & $\mathrm{Al}_{2} \mathrm{O}_{3}$ & $\mathrm{Fe}_{2} \mathrm{O}_{3}$ & MnO & $\mathrm{MgO}$ & $\mathrm{CaO}$ & $\mathrm{Na}_{2} \mathrm{O}$ & $\mathrm{K}_{2} \mathrm{O}$ & $\mathrm{P}_{2} \mathrm{O}_{5}$ \\
\hline Kulu Bay & $\mathrm{F} 1$ & 55.07 & 1.07 & 17.01 & 9.38 & 0.12 & 3.36 & 4.61 & 6.81 & 1.15 & 0.077 \\
\hline Kulu Bay & $\mathrm{F} 2$ & 71.37 & 0.40 & 15.09 & 2.90 & 0.07 & 0.19 & 1.69 & 4.83 & 4.32 & 0.087 \\
\hline Kulu Bay & F3 & 52.47 & 1.78 & 15.88 & 9.69 & 0.15 & 4.13 & 7.35 & 2.86 & 0.73 & 0.111 \\
\hline Kulu Bay & F4 & 62.98 & 1.19 & 12.12 & 9.87 & 0.06 & 2.43 & 1.30 & 4.05 & 1.03 & 0.185 \\
\hline Kulu Bay & F5 & 71.69 & 0.97 & 13.38 & 3.05 & 0.27 & 0.54 & 1.22 & 5.77 & 2.08 & 0.143 \\
\hline Kulu Bay & F6 & 59.15 & 1.83 & 12.32 & 8.15 & 0.20 & 1.93 & 9.42 & 1.58 & 0.66 & 0.121 \\
\hline Kulu Bay & F7 & 60.87 & 1.19 & 15.05 & 7.44 & 0.23 & 2.10 & 7.61 & 2.58 & 0.79 & 0.154 \\
\hline Ugaga Is & F8 & 57.32 & 0.83 & 14.75 & 8.34 & 0.21 & 2.83 & 6.36 & 4.34 & 0.19 & 0.090 \\
\hline Ugaga Is & F9 & 56.60 & 0.98 & 15.31 & 10.24 & 0.32 & 4.06 & 9.39 & 3.35 & 0.37 & 0.197 \\
\hline Natunku & F10 & 52.78 & 0.71 & 17.20 & 7.98 & 0.32 & 8.20 & 10.48 & 2.78 & 0.16 & 0.154 \\
\hline Votua & F11 & 65.14 & 0.67 & 16.80 & 4.80 & 0.13 & 0.77 & 4.40 & 4.95 & 2.37 & 0.351 \\
\hline Natunuku & $\mathrm{F} 12$ & 53.93 & 0.57 & 19.77 & 5.82 & 0.08 & 4.98 & 9.12 & 2.63 & 1.79 & 0.372 \\
\hline Natunuku & F13 & 61.35 & 1.20 & 13.69 & 8.05 & 0.20 & 2.86 & 7.08 & 2.00 & 0.69 & 0.130 \\
\hline Natunuku & F14 & 55.33 & 1.50 & 15.04 & 9.86 & 0.19 & 2.54 & 8.03 & 4.37 & 0.10 & 0.123 \\
\hline Natunuku & F15 & 53.76 & 1.04 & 15.58 & 10.14 & 0.23 & 4.71 & 12.29 & 2.37 & 0.38 & 0.134 \\
\hline Natunuku & F16 & 57.07 & 0.86 & 14.77 & 10.09 & 0.11 & 3.08 & 4.79 & 2.90 & 0.98 & 0.133 \\
\hline Kulu Bay & F17 & 55.26 & 1.48 & 15.78 & 15.26 & 0.15 & 5.17 & 4.38 & 6.86 & 0.24 & 0.122 \\
\hline Kulu Bay & F18 & 54.78 & 0.90 & 16.56 & 8.47 & 0.19 & 3.28 & 10.04 & 5.36 & 0.52 & 0.089 \\
\hline Kulu Bay & F19 & 52.41 & 7.08 & 13.44 & 13.89 & 1.62 & 3.95 & 5.97 & 3.33 & 0.96 & 0.086 \\
\hline Kulu Bay & $\mathrm{F} 20$ & 59.80 & 0.86 & 17.08 & 6.19 & 0.18 & 4.07 & 6.58 & 6.98 & 0.03 & 0.098 \\
\hline Kulu Bay & $F 21$ & 56.73 & 0.89 & 13.83 & 9.83 & 0.16 & 4.73 & 7.86 & 4.87 & 0.40 & 0.102 \\
\hline Kulu Bay & $F 22$ & 52.17 & 0.85 & 17.99 & 8.56 & 0.16 & 3.19 & 10.43 & 4.31 & 0.37 & 0.063 \\
\hline Kulu Bay & $\mathrm{F} 23$ & 65.58 & 0.91 & 14.05 & 6.95 & 0.14 & 2.51 & 7.60 & 2.80 & 0.46 & 0.128 \\
\hline Ugaga Is & $\mathrm{F} 24$ & 47.22 & 0.77 & 18.08 & 9.20 & 0.22 & 8.57 & 12.72 & 1.63 & 0.32 & 0.114 \\
\hline Kulu Bay & $\mathrm{F} 25$ & 55.02 & 0.51 & 19.56 & 5.15 & 0.09 & 2.32 & 5.98 & 4.25 & 2.70 & 0.320 \\
\hline
\end{tabular}

Note that these analyses are normalised to $100 \%$; powdered samples have analyses adding up to less than $100 \%$ and this can be much less than $100 \%$ in the case of porous samples with an uneven surface and charging effects. There is fairly good agreement between results for the two methods of preparation. Both homogeneous (F16 and F24) and non-homogeneous (F10 and F20) samples were picked for comparison (see Table 79). The analytical results for solids and powders have similar differences for homogeneous and non-homogeneous samples. This is most likely due to the care taken during analysis to avoid non-homogeneous areas of polished solids. The results indicate that samples for EDXA can be either solid or powdered. Powdered samples are generally easier to prepare and there would be an advantage to obtaining samples by drilling artefacts where minimum damage is usually desirable. Sample sizes for EDXA would require a depth of only ca. $2 \mathrm{~mm}$ for a $2 \mathrm{~mm}$ diameter drill. Note that there can be problems with contamination from drills, corers and grinding equipment. This is generally not a problem for major/minor element determinations but must be considered for trace elements.

The dendrogram of analysed Fijian lithics (Figure 162) shows close similarities between 




Figure 161. EDXA spectrum of sample F19.

Table 83. Comparison of EDXA results for powdered and solid samples. Results are normalised to $100 \%$.

\begin{tabular}{lcccccccc}
\hline & \multicolumn{2}{c}{ Natunuku } & \multicolumn{2}{c}{ Natunuku } & \multicolumn{2}{c}{ Kulu Bay } & \multicolumn{2}{c}{ Ugaga } \\
\hline & F10-S & F10-P & F16-S & F16-P & F20-S & F20-P & F24-S & F24-P \\
Oxide & Solid & Powder & Solid & Powder & Solid & Powder & Solid & Powder \\
\hline $\mathrm{SiO}_{2}$ & 52.40 & 49.82 & 60.24 & 57.36 & 58.72 & 57.56 & 47.81 & 48.88 \\
$\mathrm{TiO}_{2}$ & 0.70 & 0.56 & 0.91 & 0.81 & 0.84 & 0.68 & 0.78 & 0.90 \\
$\mathrm{Al}_{2} \mathrm{O}_{3}$ & 17.08 & 17.66 & 15.59 & 15.18 & 16.77 & 14.20 & 18.30 & 17.11 \\
$\mathrm{Fe}_{2} \mathrm{O}_{3}$ & 7.92 & 10.16 & 10.65 & 11.32 & 6.08 & 7.14 & 9.32 & 10.03 \\
$\mathrm{MnO}_{\mathrm{n} 0}$ & 0.32 & 0.16 & 0.12 & 0.30 & 0.18 & 0.19 & 0.22 & 0.18 \\
$\mathrm{MgO}_{\mathrm{O} O}$ & 8.14 & 8.42 & 3.25 & 3.87 & 4.00 & 7.04 & 8.68 & 8.07 \\
$\mathrm{CaO}$ & 10.40 & 10.35 & 5.06 & 7.41 & 6.46 & 7.63 & 12.88 & 12.04 \\
$\mathrm{Na}_{2} \mathrm{O}$ & 2.76 & 2.59 & 3.06 & 2.70 & 6.85 & 5.45 & 1.65 & 2.43 \\
$\mathrm{~K}_{2} \mathrm{O}$ & 0.16 & 0.18 & 1.03 & 0.89 & 0.03 & 0.05 & 0.32 & 0.32 \\
$\mathrm{P}_{2} \mathrm{O}_{5}$ & 0.12 & 0.09 & 0.09 & 0.17 & 0.07 & 0.05 & 0.04 & 0.06 \\
\hline
\end{tabular}




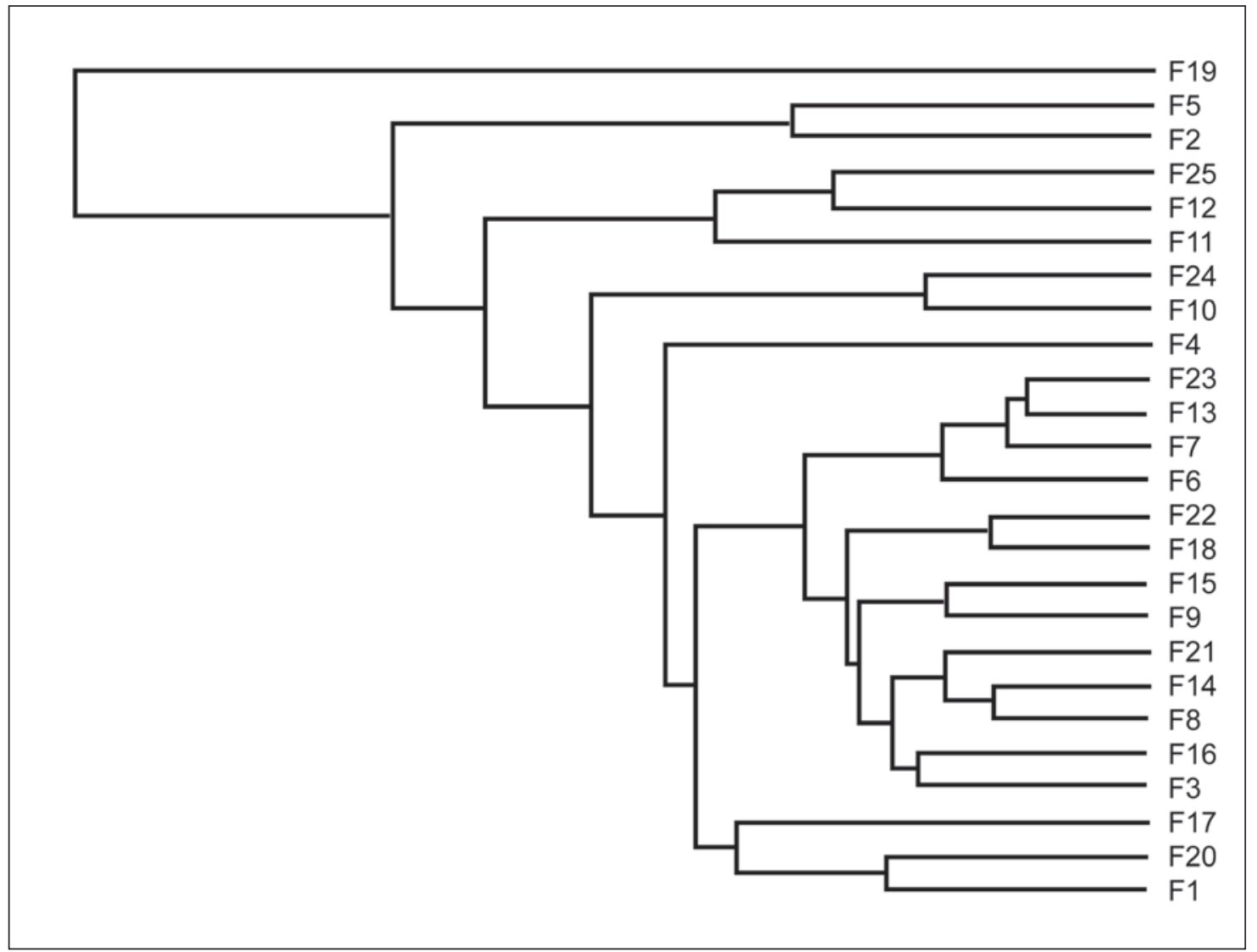

Figure 162. Hierarchical clustering report for oxide analysis of excavated flakes and adzes.

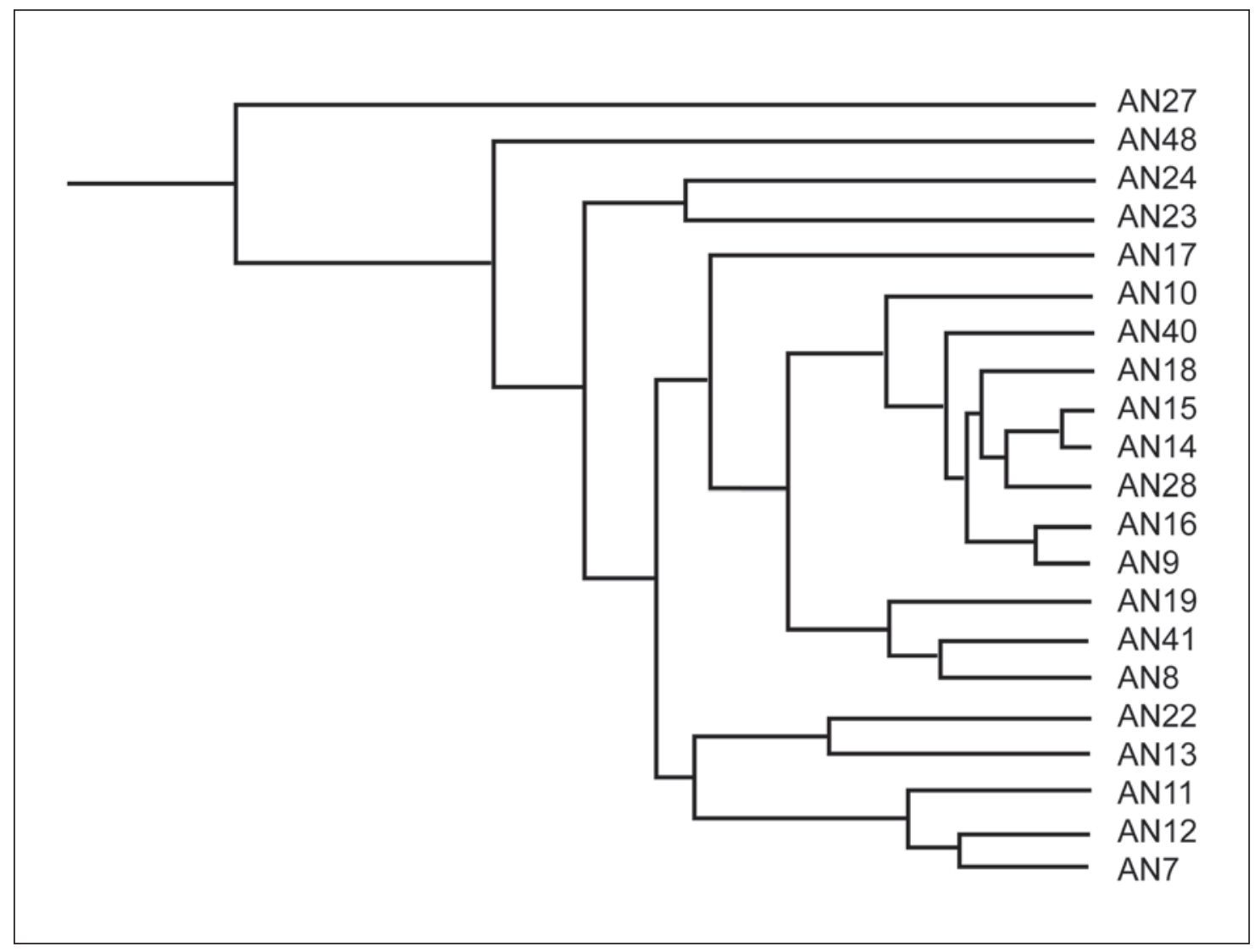

Figure 163. Hierarchical clustering report for samples from Best (1984:A74-A75). 
sample numbers: F1, F20; F2, F5; F3, F16; F6, F7, F13, F23; F8, F14, F21; F9, F15; F10, F24; F12, F25; and F18, F22. Results of visual examination of the artefacts (Tables 78 and 79) combined with cluster analysis indicate only groups F6, F7, F13; F12, F25; and F18, F22 are probably from three different sources. Samples F6 and F7 are from the same bag labelled Beqa Is, Kulu Bay, and F13 is from Natunuku VL 1/1. Sample F12 is also from Natunuku, from a depth of 10-20 cm and closely resembles F25 from Beqa Is, Kulu Bay, Sq. 11 at a depth of $30-40 \mathrm{~cm}$. In both cases, this represents inter-island use of stone from the same source. Samples F18 and F22 are from the same square at Beqa Is, Kulu Bay, but at depths of $20-30 \mathrm{~cm}$ and $110-120 \mathrm{~cm}$ respectively. This could indicate that the same stone source was being used over a long time period, but given the archaeological evidence for deposit mixing at Kulu Bay this cannot be confirmed.

All of Best's analyses (1984) for the Lau Islands and Samoan adzes and rocks are included in Table 84. The four adzes from Samoa are from Roger Green's excavations in Samoa (Green and Davidson 1969). Petrographic descriptions of most of these samples are given in Table 85 . The data matrix in Table 84 was cluster analysed.

Results for the clustering analysis of Best's data are shown in Figure 163. As expected, the results are similar to those found by Best (1984) and Best et al. (1992). Best found several Lauan adzes were closely associated with adzes and quarry material from Samoa. Lauan adzes AN16

Table 84. XRF analyses (\%) of selected adzes and rocks (from Best 1984). Note that'AN' numbers are Best's (1984) analysis numbers.

\begin{tabular}{|c|c|c|c|c|c|c|c|c|c|c|c|}
\hline Sample & Label & $\mathrm{SiO}_{2}$ & $\mathrm{TiO}_{2}$ & $\mathrm{Al}_{2} \mathrm{O}_{3}$ & $\mathrm{Fe}_{2} \mathrm{O}_{3}$ & $\mathrm{MnO}$ & $\mathrm{MgO}$ & $\mathrm{CaO}$ & $\mathrm{Na}_{2} \mathrm{O}$ & $\mathrm{K}_{2} \mathrm{O}$ & $\mathrm{P}_{2} \mathrm{O}_{5}$ \\
\hline Samoa Adze & AN7 & 47.287 & 4.228 & 13.536 & 13.695 & 0.171 & 8.034 & 8.939 & 3.181 & 1.134 & 0.624 \\
\hline Samoa Adze & AN8 & 45.306 & 4.576 & 15.331 & 14.464 & 0.188 & 5.672 & 8.093 & 3.674 & 1.218 & 0.686 \\
\hline Samoa Adze & AN9 & 48.901 & 3.103 & 15.697 & 13,321 & 0.179 & 4.556 & 7.208 & 4.382 & 1.599 & 0.966 \\
\hline Samoa Adze & AN28 & 49.635 & 3.215 & 15.469 & 13.334 & 0.178 & 4.508 & 7.51 & 4.013 & 1.719 & 0.896 \\
\hline Lakeba Adze & AN27 & 63.957 & 0.802 & 15.117 & 7.345 & 0.173 & 1.410 & 4.269 & 4.396 & 2.425 & 0.378 \\
\hline Lakeba Adze & AN10 & 46.066 & 3.162 & 14.527 & 13.014 & 0.191 & 4.539 & 7.177 & 3.833 & 1.399 & 0.984 \\
\hline Lakeba Adze & AN11 & 47.200 & 4.675 & 13.700 & 13.794 & 0.197 & 6.815 & 8.723 & 3.147 & 0.985 & 0.578 \\
\hline Lakeba Adze & AN12 & 46.897 & 4.600 & 13.938 & 13.406 & 0.164 & 6.413 & 8.505 & 3.285 & 1.015 & 0.606 \\
\hline Lakeba Adze & AN13 & 44.514 & 2.120 & 14.914 & 11.821 & 0.181 & 9.514 & 9.959 & 2.547 & 1.360 & 0.668 \\
\hline Namuka Adze & AN14 & 47.852 & 3.374 & 15.390 & 13.833 & 0.175 & 4.633 & 7.517 & 4.067 & 1.446 & 0.889 \\
\hline Kabara Adze & AN15 & 47.731 & 3.318 & 15.436 & 13.558 & 0.173 & 4.758 & 7.436 & 3.990 & 1.496 & 0.878 \\
\hline Vanuabalavu Adze & AN16 & 48.751 & 3.051 & 16.011 & 13.059 & 0.182 & 4.666 & 7.082 & 4.270 & 1.625 & 0.939 \\
\hline Taveuni Adze & AN17 & 46.414 & 4.794 & 15.724 & 14.632 & 0.127 & 5.944 & 8.380 & 3.530 & 1.214 & 0.661 \\
\hline Moce Adze & AN18 & 48.613 & 3.363 & 15.519 & 13.895 & 0.157 & 4.789 & 7.488 & 4.045 & 1.485 & 0.872 \\
\hline Fulaqa Adze & AN19 & 46.421 & 4.824 & 15.654 & 14.939 & 0.213 & 5.700 & 8.511 & 3.523 & 1.259 & 0.673 \\
\hline Kabara Rock & AN22 & 45.421 & 2.190 & 15.302 & 12.217 & 0.153 & 8.598 & 10.537 & 3.238 & 0.810 & 0.600 \\
\hline Lakeba Rock & AN23 & 44.106 & 1.363 & 13.767 & 11.840 & 0.168 & 3.775 & 7.805 & 2.834 & 0.764 & 0.292 \\
\hline Lakeba Rock & AN24 & 52.808 & 1.393 & 15.585 & 12.251 & 0.141 & 3.174 & 7.084 & 3.627 & 1.019 & 0.311 \\
\hline Samoa Leone Q. & AN40 & 48.580 & 3.340 & 15.490 & 14.080 & 0.190 & 4.790 & 7.550 & 3.680 & 1.600 & 0.880 \\
\hline Samoa Leone Q. & AN41 & 45.860 & 4.780 & 15.530 & 14.770 & 0.170 & 5.640 & 8.480 & 3.140 & 1.240 & 0.670 \\
\hline Henderson Rock & AN48 & 50.930 & 2.350 & 16.310 & 11.250 & 0.200 & 2.870 & 6.740 & 4.970 & 2.420 & 1.170 \\
\hline
\end{tabular}


Table 85. Petrographic descriptions of samples in Table 84 (from Best 1984:A70-A72).

\begin{tabular}{llll}
\hline Petrology No. & Sample & Label & Petrographic Description \\
\hline 1 & Lakeba Adze & AN27 & Glassy basalt, with small pyroxene needles and iron-oxide in volcanic glass \\
7 & Vanuabalavu Adze & AN16 & Basalt, celadonite, some small plagioclase phenocrysts, microphenocrysts of olivine \\
9 & Lakeba Adze & AN10 & Olivine basalt, celadonite replacing olivine phenocrysts, plagioclase phenocrysts \\
10 & Lakeba Adze & AN11 & Olivine basalt, similar to AN10 \\
12 & Lakeba Adze & AN12 & Olivine basalt, similar to AN10 \\
17 & Namuka Adze & AN14 & Basalt, similar to AN16 \\
20 & Kabara Adze & AN15 & Olivine basalt, felspathic, with celadonite \\
22 & Moce Adze & AN18 & Olivine basalt, similar to AN15 \\
23 & Fulaqa Adze & AN19 & Olivine basalt, similar to AN15 \\
26 & Lakeba Adze & AN13 & Alkaline olivine basalt, with titaniferous augite \\
94 & Lakeba Rock & AN23 & Fine-grained felspathic basalt \\
96 & Lakeba Rock & AN24 & Fine-grained felspathic basalt with celadonite-filled cavities \\
101 & Kabara Rock & AN22 & Olivine basalt, olivine phenocrysts, microphenocrysts of plagioclase, iron oxide \\
105 & Samoa Adze & AN7 & Olivine basalt (olivine phenocrysts); groundmass with augite and ores \\
106 & Samoa Adze & AN8 & Olivine feldspar basalt; contains green and brown celadonite in cavities \\
107 & Samoa Adze & AN9 & Felspathic basalt; contains brown biotite (celadonite) \\
\hline
\end{tabular}

and AN10 were thought to be from Tutuila and are grouped as such, with AN10 being an outlier. The Samoan adze (AN28, AN9, AN8) and quarry (AN40, AN41) samples form a large cluster with several Lauan adzes (Lakeba AN10, Moce AN18, Kabara AN15, Namuka AN14, Vanuabalavu AN16 and Fulaga AN19). The larger cluster can be divided into two smaller clusters, which was also noted by Best (1984:403). One Samoan adze sample forms a cluster with Lakeba adzes AN11 and AN12. It can be seen in Figure 163 that some Lauan adzes are closely linked with Samoan adzes and quarry samples. Best concluded the adzes were sourced to Samoa and specifically to Tutuila. According to Best (1984:403), AN23 and AN24 are rock samples from the two mineralogically nearest sources. They are linked, but not closely. Lakeba adze AN13 and an andesitic-basalt from Delaioloi (Kabara, AN22) are similar.

The dendrogram in Figure 164 has the results of a cluster analysis for the analyses from Best (Table 84) and excavated Fiji flakes and adze fragments (Table 82; also compare Figures 162 and 163). Interestingly, there are few closely associated artefacts among Best's samples and those of the current project. None of the excavated samples is closely associated with the Samoan material. This could be expected given that no adzes resembling those of a Samoan origin were available for analysis. In addition, flakes would be unlikely to have a Samoan origin given that Samoan adzes would have been imported in finished form and the only possibility of finding flakes sourced to Samoa would be flakes from retouching adzes.

However, there are a few linked samples. These include AN27, F11; AN24, F3, F16; and less so with AN23, connected to a group of samples from the present project. Best found that Lakeba rock (AN23 and AN24) clustered by itself in a ternary diagram. This most likely indicates a local source of rock for associated samples in this project. Although the analysis of a 


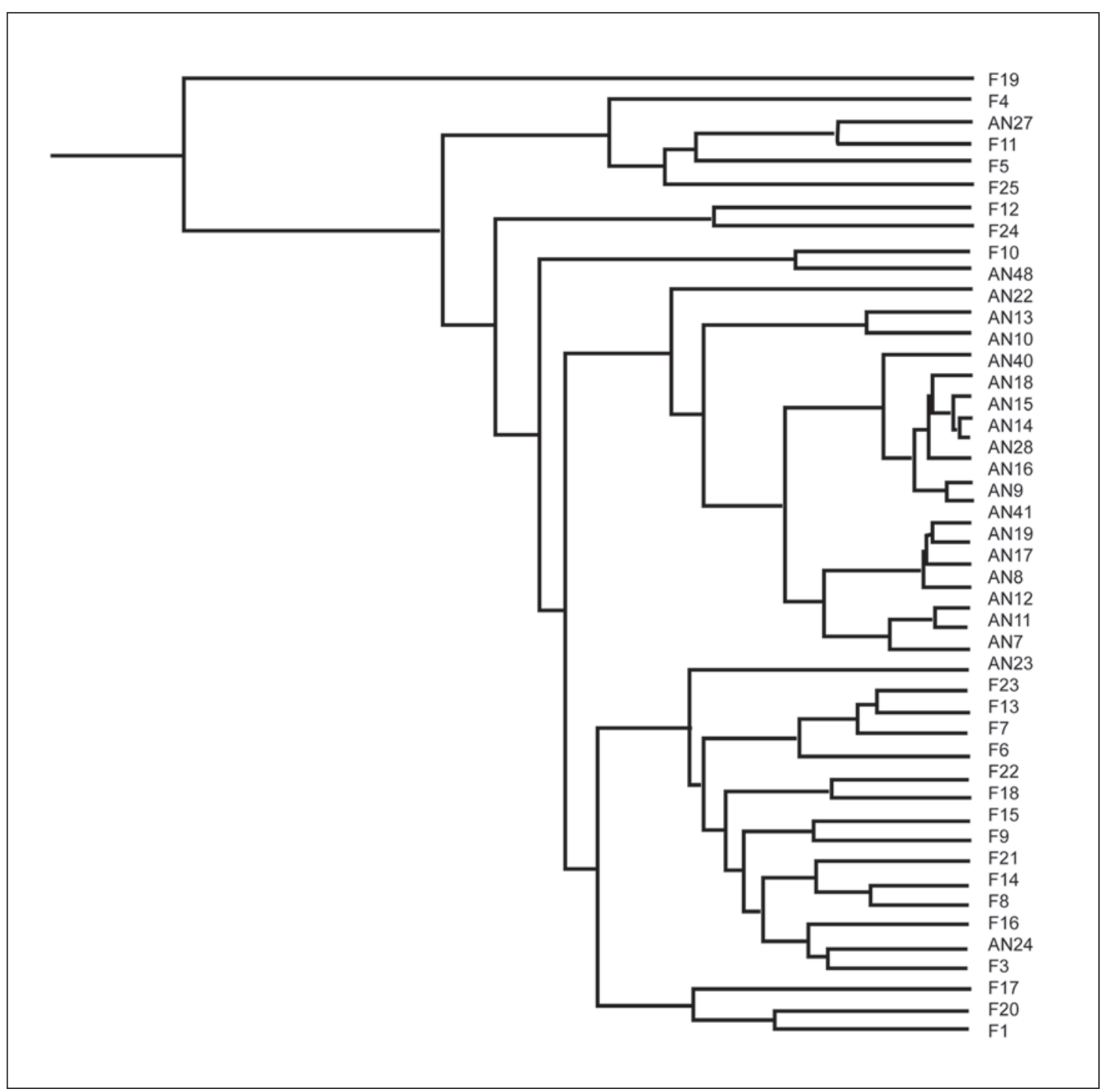

Figure 164. Hierarchical clustering report for excavated samples and Best (1984:A74-A75).

Lakeba adze (AN27) appears in Best (1984:A70, A74) it 'disappears' from further consideration there and in Best et al. (1992). Note that it is an outlier in Figure 163 but is clustered here with F11 and F5 (Figure 164). However, its petrographic description (Tables 78 and 79) does not resemble those of the latter samples, and it most likely is not from the same source.

Additional selected samples from the database will now be considered (see Table 86). Several samples were obtained from sites on American Samoa and some were sourced to Samoa (e.g. RW-M and RW-F labelled Ma'uke in Best et al. 1992), with other Cook Island samples likely to be from Samoa (Sheppard et al. 1997:101-103).

Results of cluster analysis for all samples with major/minor elemental analyses considered in this report are presented in Figure 165. Note that the dendrogram is split into two sections. A large cluster is formed, with AN23 and AN24 linked closely with Alega 1 and F3 and less so for several other excavated (F) samples. Another large cluster contains mostly Samoan samples, with closely associated Lauan adzes and samples from other island groups having artefacts possibly sourced to Samoa. Some Hawaiian samples form a group which includes AN23 and AN13 (previously found to be off by themselves in Best's ternary diagram), but there is unlikely to be 
Table 86. Additional basalt reference samples (oxides in \%).

\begin{tabular}{|c|c|c|c|c|c|c|c|c|c|c|c|c|c|}
\hline Reference & Archipelago & Information & Label & $\mathrm{SiO}_{2}$ & $\mathrm{TiO}_{2}$ & $\mathrm{Al}_{2} \mathrm{O}_{3}$ & $\mathrm{Fe}_{2} \mathrm{O}_{3}$ & MnO & Mg0 & $\mathrm{CaO}$ & $\mathrm{Na}_{2} \mathrm{O}$ & $\mathrm{K}_{2} \mathrm{O}$ & $\mathrm{P}_{2} \mathrm{O}_{5}$ \\
\hline Clark et al. 1997:75 & A. Samoa & Weisler & Taputapu & 49.56 & 3.38 & 15.35 & 13.72 & 0.17 & 4.55 & 7.56 & 3.96 & 1.54 & 0.79 \\
\hline Clark et al. 1997:75 & A. Samoa & TUT-II.2 & Asiapa & 50.24 & 2.94 & 16.01 & 12.87 & 0.18 & 4.11 & 7.26 & 3.99 & 1.77 & 1.25 \\
\hline Clark et al. 1997:75 & A. Samoa & TUT-II.3 & Le'aeno & 47.80 & 3.71 & 16.09 & 12.74 & 0.18 & 4.84 & 7.71 & 3.65 & 1.61 & 0.76 \\
\hline Clark et al. 1997:76 & A. Samoa & $\mathrm{H} 1$ & Fagasa & 48.90 & 3.19 & 15.90 & 13.24 & 0.19 & 4.45 & 7.21 & 3.71 & 1.70 & 0.84 \\
\hline Clark et al. 1997:76 & A. Samoa & TUT-II.7 & Alega 1 & 49.80 & 3.16 & 15.50 & 12.09 & 0.18 & 4.07 & 7.39 & 3.56 & 1.61 & 0.08 \\
\hline Clark et al. 1997:76 & A. Samoa & TUT-II.4 & Lau'agae & 47.95 & 3.82 & 15.96 & 13.91 & 0.16 & 4.89 & 7.71 & 3.63 & 1.51 & 0.73 \\
\hline Clark et al. 1997:76 & A. Samoa & TUT-11.10 & Nu'u'uli & 52.80 & 2.03 & 16.30 & 9.25 & 0.17 & 3.23 & 6.10 & 4.20 & 2.20 & 1.25 \\
\hline $\begin{array}{l}\text { Weisler and Sinton } \\
\text { 1997:179 }\end{array}$ & A. Samoa & & $\begin{array}{l}\text { Tataga- } \\
\text { matau }\end{array}$ & 48.52 & 3.42 & 15.51 & 13.66 & 0.18 & 4.79 & 7.54 & 3.76 & 1.55 & 0.78 \\
\hline $\begin{array}{l}\text { Allen and Johnson } \\
\text { 1997:121 }\end{array}$ & Cook Islands & 5 & Aitutaki & 49.58 & 3.13 & 15.90 & 13.39 & 0.17 & 4.53 & 7.54 & 3.54 & 1.64 & 0.90 \\
\hline $\begin{array}{l}\text { Sheppard et al. } \\
\text { 1997:96 }\end{array}$ & Cook Islands & R63-19 & Rarotonga & 48.17 & 2.65 & 16.24 & 11.96 & 0.24 & 4.13 & 6.86 & 4.42 & 1.82 & 1.00 \\
\hline $\begin{array}{l}\text { Sheppard et al. } \\
\text { 1997:96 }\end{array}$ & Cook Islands & RAR-6 & Rarotonga & 47.83 & 3.04 & 16.13 & 13.08 & 0.21 & 4.50 & 7.24 & 3.95 & 1.68 & 0.83 \\
\hline $\begin{array}{l}\text { Sheppard et al. } \\
\text { 1997:96 }\end{array}$ & Cook Islands & R92-1 & Rarotonga & 47.21 & 3.16 & 15.75 & 13.07 & 0.22 & 4.73 & 7.19 & 3.70 & 1.63 & 0.78 \\
\hline $\begin{array}{l}\text { Sheppard et al. } \\
\text { 1997:96 }\end{array}$ & Cook Islands & RW-M & Ma'uke & 47.92 & 3.43 & 15.53 & 13.57 & 0.21 & 4.77 & 7.74 & 3.91 & 1.54 & 0.81 \\
\hline $\begin{array}{l}\text { Sheppard et al. } \\
\text { 1997:96 }\end{array}$ & Cook Islands & RW-F & Ma'uke & 49.45 & 2.73 & 16.61 & 11.91 & 0.20 & 4.19 & 7.13 & 4.55 & 1.88 & 1.00 \\
\hline $\begin{array}{l}\text { Weisler and Sinton } \\
\text { 1997:179 }\end{array}$ & Pitcairn & & Tautama & 49.93 & 2.68 & 15.57 & 13.45 & 0.22 & 3.49 & 7.09 & 4.55 & 1.99 & 1.25 \\
\hline $\begin{array}{l}\text { Weisler and Sinton } \\
\text { 1997:179 }\end{array}$ & Marquesas & & Eiao & 46.95 & 3.90 & 15.23 & 13.53 & 0.16 & 6.47 & 9.32 & 3.18 & 1.00 & 0.54 \\
\hline $\begin{array}{l}\text { Weisler and Sinton } \\
\text { 1997:181 }\end{array}$ & Hawaii & Kaho'olawe & Pu'umaiwi & 52.37 & 2.98 & 14.02 & 13.18 & 0.17 & 4.60 & 8.37 & 3.00 & 0.85 & 0.88 \\
\hline $\begin{array}{l}\text { Sinton and Sinoto } \\
1997: 200\end{array}$ & Hawaii & Hawai'i & Mauna Kea & 47.99 & 3.95 & 13.44 & 15.32 & 0.21 & 5.07 & 9.58 & 3.08 & 1.13 & 0.56 \\
\hline $\begin{array}{l}\text { Sinton and Sinoto } \\
\text { 1997:200 }\end{array}$ & Hawaii & Maui & Haleakala & 51.00 & 2.02 & 17.49 & 10.57 & 0.25 & 2.49 & 6.27 & 6.25 & 2.25 & 0.88 \\
\hline $\begin{array}{l}\text { Sinton and Sinoto } \\
1997: 200\end{array}$ & Hawaii & Lana'i & Kapohaku & 51.48 & 2.11 & 13.96 & 12.11 & 0.16 & 7.10 & 10.06 & 2.29 & 0.52 & 0.25 \\
\hline $\begin{array}{l}\text { Sinton and Sinoto } \\
\text { 1997:200 }\end{array}$ & Hawaii & Ovahu & Waiahole & 52.81 & 2.19 & 13.77 & 11.37 & 0.15 & 6.54 & 9.14 & 2.69 & 0.71 & 0.34 \\
\hline $\begin{array}{l}\text { Sinton and Sinoto } \\
\text { 1997:202 }\end{array}$ & \multicolumn{2}{|l|}{ Easter Island } & Ova he & 51.28 & 2.46 & 14.69 & 13.96 & 0.22 & 3.29 & 7.16 & 3.91 & 1.32 & 0.82 \\
\hline $\begin{array}{l}\text { Sinton and Sinoto } \\
\text { 1997:203 }\end{array}$ & \multicolumn{2}{|c|}{ Society Islands Ra'iatea } & Ra'iatea II & 42.37 & 4.54 & 15.07 & 13.83 & 0.18 & 5.16 & 10.69 & 3.72 & 1.82 & 0.64 \\
\hline $\begin{array}{l}\text { Sinton and Sinoto } \\
\text { 1997:203 }\end{array}$ & Society Islands & Tahiti & Tahinu II & 42.73 & 3.93 & 15.15 & 13.83 & 0.19 & 5.01 & 10.45 & 3.65 & 1.98 & 0.67 \\
\hline
\end{tabular}




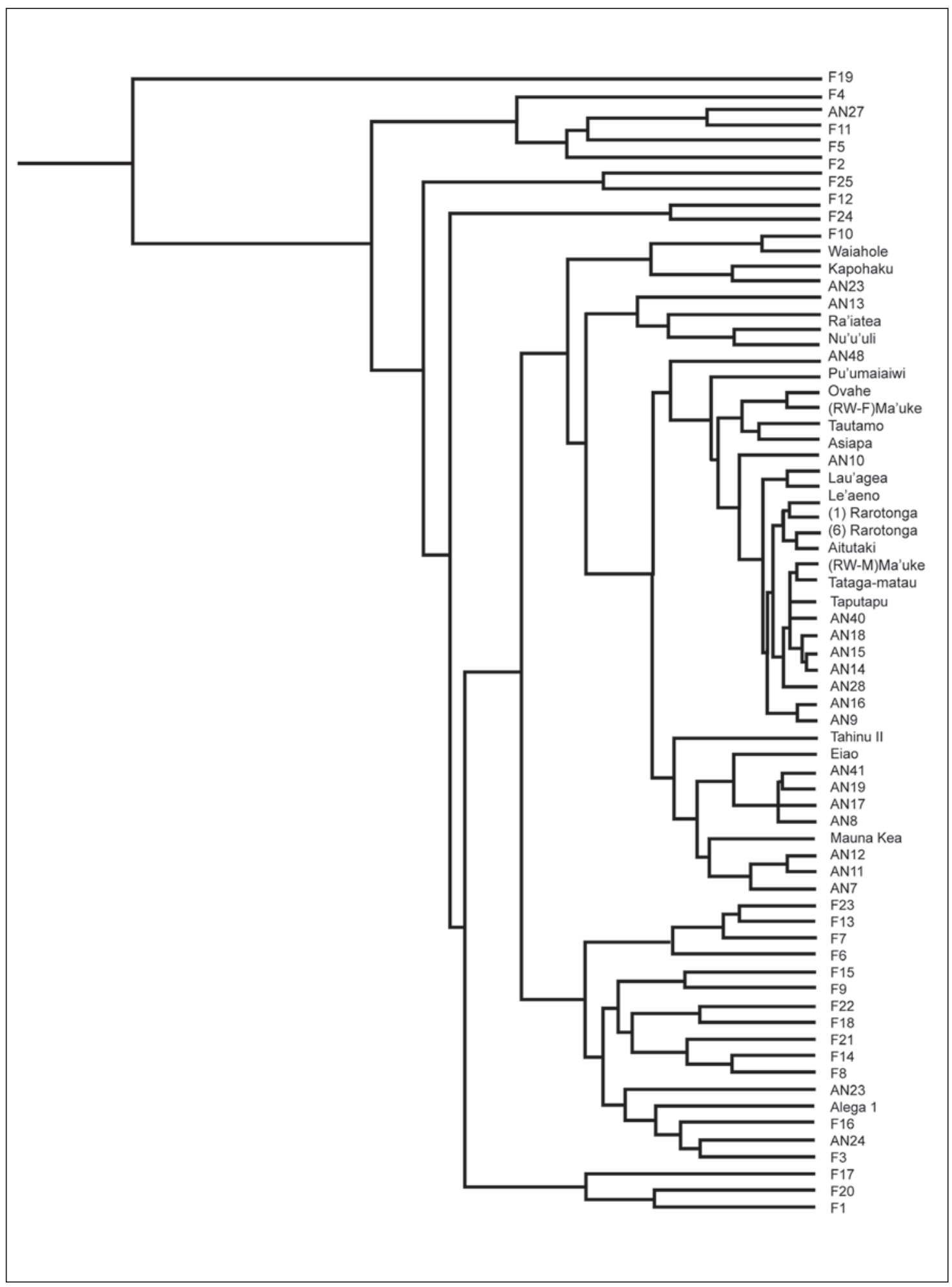

Figure 165. Hierarchical clustering report for excavated and all reference samples. 
any relationship between samples from Hawaii and Fiji. What is clear here is that several Lauan adzes have their origin in Samoa and are most likely from Leone (Tutuila). The sample from Alega is out of place here. According to Clark et al. (1997:76), Alega samples cluster tightly with the bulk of the Fagasa samples. Alega 1 cannot be associated with source rock from Lakeba.

\section{Trace elements}

Table 87 gives the ICP-MS results for trace-element analysis of the excavated flakes and adzes. Nineteen elements were included in the analyses. The limit of detection was 1 part per million $(1 \mu \mathrm{g} / \mathrm{g})$ for $\mathrm{Nb}, \mathrm{Ni}, \mathrm{Pb}$ and $\mathrm{Th}$, and $5 \mathrm{ppm}$ for As. Values below this limit are indicated by a < sign. Note that these limits of detection are to some extent laboratory dependent and the actual limit of detection with ICP-MS for these elements is < 1 part per billion (Rubinson 1987:227228). Literature and determined values for BHVO-1 are presented. In addition to some being

Table 87. ICP-MS analysis results (ppm) for excavated adzes and adze flakes from Fiji.

\begin{tabular}{|c|c|c|c|c|c|c|c|c|c|c|c|c|c|c|c|c|c|c|c|c|}
\hline ample & Analy & is & Ba & & $\mathrm{Cr}$ & u & $\mathrm{Ga}$ & La & $\mathrm{Mb}$ & Nd & $\mathrm{Ni}$ & $\mathrm{Pb}$ & b & c & Sr & Th & V & $Y$ & Zn & $\mathrm{Zr}$ \\
\hline & & & & & 16.3 & & 16.3 & 2.6 & 3.2 & & & 5 & .9 & & & & 4.4 & 8.6 & 67.0 & 33.7 \\
\hline & 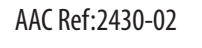 & $<5$ & 1 & & 3.7 & 2 & 15.8 & 16.5 & 10.6 & $2+2$ & & 5 & 6 & .6 & 1 & 3 & 5.8 & 6.7 & 88.5 & 240 \\
\hline & $A A C B$ & 5 & 1 & 3 & 13.4 & 12 & 18.0 & 2.8 & 2 & 7.9 & 9.2 & 2.4 & 6 & 36.6 & 216.8 & 5 & 339.3 & .1 & 121.5 & 63 \\
\hline & 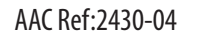 & 45 & 479.8 & 11.4 & 7 & 5 & 15. & 5 & 6 & 1 & 6.0 & 8 & .2 & 1 & 20 & 9 & 8.5 & 4.6 & 168.3 & 87.5 \\
\hline & $\triangle A C$ Bef. 2 & & 411.3 & 16.8 & $3+3$ & 1 & 10 & 6 & $3+2>$ & 1 & 3.7 & 8 & 9 & 7 & 1 & 12 & 3 & .7 & 3.9 & 1 \\
\hline & $A A C$ Ref. $\cdot 2$ & 39.5 & 176.6 & 9. & 7 & 6 & 16 & 3.1 & 3.8 & 8.5 & 6.2 & 1.4 & 0 & .0 & 46 & 0 & 2 & .7 & 6.5 & 74.3 \\
\hline & $A A C$ Ref. $2 A$ & 17.4 & 267.4 & 9.5 & 8.4 & 3 & 16. & 3.6 & 4.7 & 9.7 & 8.2 & 1.3 & 1 & .5 & 4 & 1.1 & .4 & .5 & 0.0 & 66.1 \\
\hline & $A A(R \circ f)$ & & 101.7 & 5.7 & 10.4 & 6.5 & 12 & 2.9 & 1.8 & 7.1 & 12.0 & 1.0 & 38 & .0 & 22 & 1.0 & 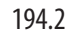 & 24.9 & .2 & 73.4 \\
\hline & 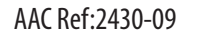 & 42.5 & 323.1 & 9.3 & 17 & 9.3 & 17 & $2+2>$ & 6 & 9.4 & & 6.4 & 9 & 4 & 3 & 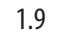 & 8 & .9 & 4 & 50.1 \\
\hline & AACRef: & & 72.2 & 11.7 & 271.4 & 44.4 & 152 & 4 & $<$ & 86 & 10 & 2.0 & 6 & 1 & 18 & $<1$ & 3.4 & 6.6 & 81.2 & 51.1 \\
\hline & $A \wedge C D, f$ & & $7 \varepsilon$ & 32.6 & 28 & 29.5 & 16.9 & 13.6 & 6.6 & 22.1 & $<1$ & .9 & .0 & .6 & & 2.J & 32.0 & 7.6 & 111.0 & 1 \\
\hline & $\mathrm{mi}$ & 0.1 & & 18.3 & 8 & 95.0 & 17. & 9.1 & 5.5 & 13.1 & 1 & 2.6 & .0 & 2 & 8 & .0 & 265.3 & .7 & 91.7 & 58.0 \\
\hline & A & $<$ & 51 & 11.7 & 12.9 & 64.2 & 16. & 3.8 & 35.5 & 11 & & 1.1 & 11.4 & 28.8 & 373.8 & $<1$ & & 9.5 & 129.4 & 68.8 \\
\hline & Af & $<5$ & 279 & 10.1 & 10.0 & 89.3 & 17. & 3. & 4. & & & 1.0 & 4 & 33.5 & & -1 & & 9.0 & 112.5 & 75. \\
\hline 15 & $\mathrm{AACP}$ & $<5$ & & 2.8 & 15.6 & 9 & 15. & 1.1 & 30.2 & 2.8 & & 1.1 & 7.0 & 39.0 & 167.6 & $<1$ & & 5.6 & 73.4 & 45.0 \\
\hline 16 & $A A C R$ & $<5$ & 502.4 & 10.7 & 10.8 & 67.7 & 17.6 & 7.0 & 30.2 & 15.3 & 11 & 1.1 & 19.9 & 32.4 & 309.5 & $<1$ & & 5.9 & 125.2 & 54. \\
\hline & Af & $<5$ & 5 & 6.6 & 13.8 & 643.6 & 20.9 & 2.5 & 4.6 & 6.7 & 13. & 1.0 & .5 & 39.9 & 14 & $<$ & & 26.1 & 74.0 & 50.7 \\
\hline 18 & A & -5 & $10.2->$ & 4.0 & 9.8 & 148.2 & 16.6 & 1.9 & 2. & 4.9 & 17. & $<1$ & 22.8 & 42.2 & 298.7 & 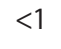 & .5 & 25.3 & 99.0 & 87.8 \\
\hline 19 & AAC Ref:2 & 130.4 & 175 & 6.0 & 11.4 & 213.3 & 17. & 2. & 1.2 & 5.8 & 14. & 4.7 & 22.2 & 40.3 & 106.2 & 1 & 8.0 & 19.8 & 93.2 & 34 \\
\hline 20 & AAC Ref: & $<$ & $2+2$ & 1.6 & 16.5 & 17.0 & 15. & $<1$ & 23.1 & 1.9 & 14 & $<1$ & 1.6 & 28.5 & 93.1 & $<1$ & 5.1 & 17.6 & 106.3 & 30 \\
\hline F21 & AAC Ref:2 & $<5$ & 534 & 3.8 & 15.1 & 28.3 & 14. & 2.0 & $<1$ & 3.7 & 13. & $<1$ & 9.3 & 40.5 & 102.2 & $<1$ & 340.8 & 20.8 & 50.1 & 47 \\
\hline 22 & $C R$ & $<5$ & 1479 & 2.2 & 26.8 & 48.3 & 12.0 & $<1$ & 2.0 & 1.5 & 18. & $<1$ & 5.6 & 28.4 & 230.6 & 1 & 201.1 & 10.3 & 93.6 & 60 \\
\hline 33 & $\left.C \mathrm{P}_{f}\right)_{-1}$ & $<5$ & 333.1 & 7.2 & 65 & 46.3 & 14.0 & 24 & 1.5 & 6.6 & $7 !$ & $<1$ & 7.2 & 27.7 & 223.4 & 1 & 153.7 & 26.5 & 89.1 & $51>$ \\
\hline 24 & $\mathrm{AAC} R$ & -5 & 868 & 5.3 & 389.3 & 46.0 & 16.1 & 1.8 & $<1$ & 4.9 & 1232 & $<1$ & 2.7 & 33.7 & 111.4 & 1 & 268.0 & 13.1 & 76.4 & 34 \\
\hline 25 & $\mathrm{AAC} R$ & $<5$ & 337.4 & 23.0 & 58.7 & 145.9 & 18.7 & 11.1 & 3.1 & 17.0 & 24. & 2.6 & 33.5 & 32.6 & 535. & 1 & 272.7 & 24.9 & 93.0 & $80-2>$ \\
\hline vo & D & $<$ & 129 & 36.4 & 257.4 & 136.0 & 22.0 & 16.2 & 19.3 & 21.6 & 115.1 & 2.0 & 13.7 & 32.1 & 318.9 & 1.0 & 310.3 & 25.5 & 116.4 & 18 \\
\hline S & Lit. Value & 0.4 & 139.0 & 39.0 & 289.0 & 136.0 & 21.0 & 15.8 & 19.0 & 25.2 & 121.0 & 2.6 & 11.0 & 31.8 & 4030 & 1 & 317.0 & 27.6 & 105.0 & 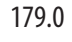 \\
\hline
\end{tabular}


below the level of detection, values for $\mathrm{Th}$ and $\mathrm{Pb}$ were low and too similar to be of use and were removed from the data set. Because arsenic (As) results appear useful for discrimination, values $<5$ were set to 1 . Other elements with values $<1$ were set to 0.1 . The element values were further corrected to reflect the standard BHVO-1.

Cluster analysis for the trace-element analysis of Fijian excavated material is given in Figure 166. NCSS has divided the results into four clusters with six outliers. Cluster 1 contains F10, F24; Cluster 2: F13, F16; Cluster 3: F2, F11; and Cluster 4: F1, F21, F18, F8, F23, F22, F4, F6, F14, F15, F20, F9, F19. Closely linked (similar) samples include F1, F21, (F18); F8, F23, (F22); F6, F14, (F4); F15, F20; F13, F16; and F10, F24. Note that samples not as closely linked are indicated within parentheses. Other samples which are linked include F2, F11; F12, F25; F9, F19. Note that the clustering analysis of trace elements for Fiji where all elements are used is similar to clustering with a reduced number of elements. The exception is that F9 and F19 are linked with the full data set.

Linkages common to dendrograms for major/minor and trace elements (Figures 162 and 166) are: F12, F25 (and similar petrology); F10, F24 (petrology different); F8, F22, F23 (similar petrology); and F6, F14 (similar petrology). These commonly linked samples should be considered as coming from the same sources. Samples F10 and F24 do not appear the same petrologically but differential weathering may be involved and they may be from the same source.

Ideally, the same samples which were used to form Table 86 for the oxides should have been considered for trace elements. The trace-element database unfortunately does not contain any samples of possible Fijian origin for comparison with the excavated material. Best (1984) and Best et al. (1992) have results only for oxides (Table 84) of Fijian lithics. The table of reference

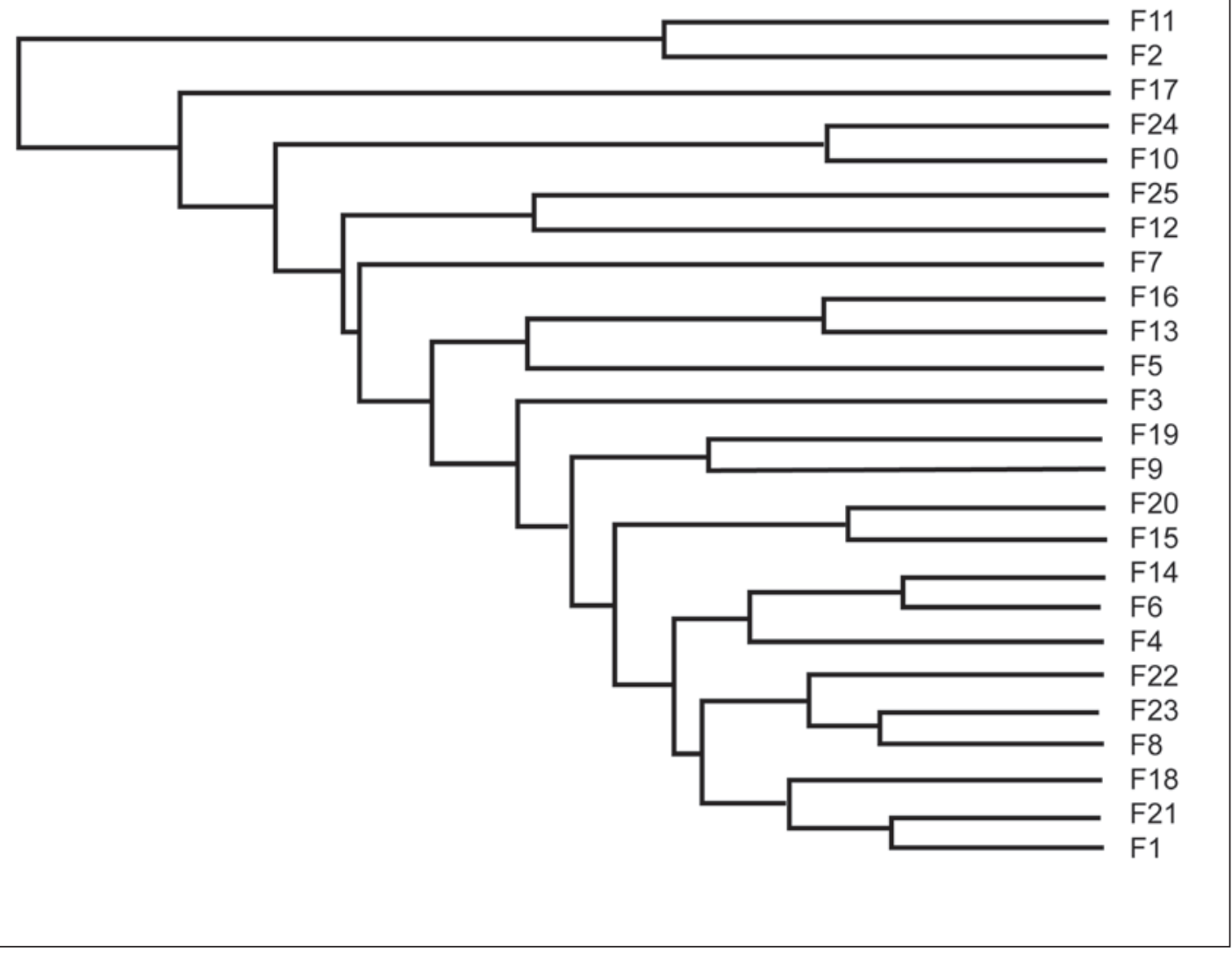

Figure 166. Hierarchical clustering report for trace-element analysis of Fiji excavated flakes and adze fragments. 
samples contains analyses of flakes either directly or indirectly sourced to American Samoa and other lithic material from Polynesia (see Table 88). Several of these references are unlikely to have a connection with the excavated artefacts, but they were included to see how they would cluster.

Trace-element analyses for excavated adzes and flakes, along with selected reference samples, are shown in Table 89. The samples in this table have only 11 analysed elements in common, although the original analyses contained more. The data matrix was cluster analysed.

Results of the cluster analysis are given in Figure 167. Most of the excavated samples cluster together and away from the reference samples. This would be expected because there are no likely source rocks in the reference database to link with the Fijian artefacts. It can be seen that samples from Samoa are closely linked and form a cluster, although Tautama and Ovahe are in the cluster but not closely linked. Sample AN41 is linked with F7, but it should be in the Samoan cluster and this appears to be a faulty chemical analysis. Some of the linkages indicate the similarities in trace-element make-up of certain basalts from widely separated sources. At this time, it appears that major-element analyses were of more use than trace elements because of the availability of reference samples.

Table 88. Trace-element analyses (ppm) for basalt references.

\begin{tabular}{|c|c|c|c|c|c|c|c|c|c|c|c|c|c|c|}
\hline Reference & Archipelago & Information & Label & v & $\mathrm{Cr}$ & $\mathrm{Ni}$ & Cu & $\mathrm{Zn}$ & $\mathbf{R b}$ & $\mathrm{Sr}$ & $Y$ & $\mathrm{Zr}$ & $\mathrm{Mb}$ & $\mathrm{Ba}$ \\
\hline Best et al. 1992:85 & Cook Islands & Ma'uke & Cooksl & 279 & 0 & 54 & 42 & 159 & 27 & 598 & 42 & 347 & 39 & 264 \\
\hline Best et al. 1992:85 & Cook Islands & Ma'uke & Cooks2 & 248 & 0 & 19 & 34 & 110 & 20 & 717 & 33 & 241 & 63 & 370 \\
\hline Best et al. 1992:85 & A. Samoa & Flake, Area 1 & 15 (TTM-A1) & 221 & 0 & 0 & 7 & 195 & 44 & 710 & 50 & 406 & 44 & 297 \\
\hline Best et al. 1992:85 & A. Samoa & Flake, Area 1 & 17 (TTM-A1) & 214 & 0 & 0 & 8 & 191 & 38 & 720 & 50 & 406 & 42 & 330 \\
\hline Best et al. 1992:85 & A. Samoa & Flake, Area 3 & 23 (ТTM-A3) & 209 & 0 & 6 & 15 & 190 & 41 & 721 & 50 & 407 & 44 & 314 \\
\hline Best et al. 1992:85 & A. Samoa & Flake, Leone & AN40 & 197 & 0 & 0 & 0 & 197 & 50 & 742 & 51 & 424 & 44 & 326 \\
\hline Best et al. 1992:85 & A. Samoa & Flake, Leone & AN41 & 305 & 0 & 41 & 26 & 549 & 28 & 622 & 43 & 350 & 40 & 271 \\
\hline Best et al. 1992:85 & A. Samoa & $\| .2$ & Asia pa & 153 & 0 & 17 & 23 & 193 & 41 & 755 & 55 & 451 & 48 & 426 \\
\hline Sinton and Sinoto 1997:201 & A. Samoa & Tutuila & Maupua & 198 & 1 & 36 & 30 & 150 & 342 & 107 & 50 & 473 & 60 & 317 \\
\hline Sinton and Sinoto 1997:201 & A. Samoa & TUT-II.3 & Le'aeno & 247 & 0 & 23 & 25 & 181 & 39 & 764 & 43 & 391 & 47 & 303 \\
\hline Sinton and Sinoto 1997:201 & A. Samoa & Tutuila & Tataga-matau & 210 & 1 & 0 & 5 & 182 & 42 & 708 & 49 & 383 & 49 & 305 \\
\hline Sinton and Sinoto 1997:201 & Pitcairn & & Tautama & 109 & 8 & 1 & 15 & 171 & 39 & 589 & 48 & 417 & 89 & 458 \\
\hline Sinton and Sinoto 1997:201 & Marquesas & & Eiao & 297 & 87 & 100 & 47 & 130 & 18 & 591 & 37 & 306 & 28 & 187 \\
\hline Sinton and Sinoto 1997:200 & Hawaii & Kaho'olawe & Pu'umoiwi & 345 & 59 & 60 & 75 & 145 & 16 & 396 & 65 & 228 & 17 & 299 \\
\hline Sinton and Sinoto 1997:200 & Hawaii & Hawai'i & Mauna Kea & 427 & 0 & 30 & 35 & 137 & 30 & 538 & 39 & 314 & 44 & 405 \\
\hline Sinton and Sinoto 1997:200 & Hawaii & Maui & Haleakala & 38 & 6 & 0 & 8 & 133 & 55 & 1105 & 41 & 412 & 77 & 886 \\
\hline Sinton and Sinoto 1997:200 & Hawaii & Lana'i & Kapohaku & 304 & 291 & 118 & 103 & 106 & 7 & 357 & 64 & 136 & 10 & 97 \\
\hline Sinton and Sinoto 1997:200 & Hawaii & O'ahu & Waiahole & 272 & 225 & 123 & 106 & 104 & 10 & 445 & 25 & 167 & 10 & 119 \\
\hline Sinton and Sinoto 1997:202 & Easter Island & & Ovahe & 162 & 1 & 7 & 5 & 154 & 28 & 299 & 74 & 459 & 53 & 260 \\
\hline Sinton and Sinoto 1997:203 & Society Islands & Ra'iatea & Ra'iatea II & 158 & 8 & 3 & 12 & 118 & 63 & 1882 & 42 & 433 & 74 & 864 \\
\hline Sinton and Sinoto 1997:203 & Society Islands & Tahiti & Tahinu II & 381 & 1 & 53 & 110 & 114 & 53 & 740 & 34 & 311 & 60 & 587 \\
\hline
\end{tabular}


Table 89. Trace-element analyses (ppm) for excavated and selected reference samples.

\begin{tabular}{|c|c|c|c|c|c|c|c|c|c|c|c|c|}
\hline Sample & Label & V & $\mathrm{Cr}$ & $\mathrm{Ni}$ & $\mathrm{Cu}$ & $\mathrm{Zn}$ & $\mathbf{R b}$ & $\mathrm{Sr}$ & $Y$ & $\mathrm{Zr}$ & $\mathrm{Nb}$ & $\mathrm{Ba}$ \\
\hline Kulu Bay & F1 & 321.1 & 18.3 & 9.8 & 85.3 & 60.4 & 13.6 & 216.8 & 19.1 & 33.1 & 3.1 & 144.7 \\
\hline Kulu Bay & F2 & 5.9 & 4.1 & 0.1 & 27.7 & 79.8 & 64.2 & 159.5 & 39.7 & 235.9 & 10.4 & 1193.5 \\
\hline Kulu Bay & F3 & 346.5 & 15.0 & 9.7 & 126.2 & 109.6 & 7.8 & 274.0 & 28.3 & 61.9 & 2.8 & 1279.3 \\
\hline Kulu Bay & F4 & 141.5 & 8.6 & 6.3 & 52.7 & 151.8 & 8.2 & 257.6 & 37.5 & 85.8 & 6.3 & 513.9 \\
\hline Kulu Bay & F5 & 32.0 & 3.8 & 3.9 & 10.3 & 120.8 & 13.6 & 161.5 & 61.4 & 123.7 & 3.6 & 440.5 \\
\hline Kulu Bay & F6 & 188.2 & 8.4 & 6.5 & 60.2 & 96.1 & 6.4 & 590.6 & 32.2 & 72.9 & 3.7 & 189.2 \\
\hline Kulu Bay & F7 & 158.8 & 9.4 & 8.6 & 35.5 & 360.8 & 16.2 & 570.1 & 36.3 & 64.8 & 4.7 & 286.4 \\
\hline Ugaga Is. & F8 & 198.4 & 11.7 & 12.6 & 6.5 & 63.3 & 3.0 & 287.9 & 27.0 & 72.0 & 1.8 & 108.9 \\
\hline Ugaga Is. & F9 & 255.2 & 19.9 & 11.8 & 9.3 & 85.2 & 14.4 & 379.1 & 28.1 & 49.1 & 6.3 & 346.0 \\
\hline Natunuku & F10 & 274.2 & 304.7 & 112.2 & 44.4 & 73.3 & 1.3 & 235.6 & 18.0 & 50.1 & 0.1 & 77.3 \\
\hline Votua & F11 & 32.7 & 3.1 & 0.1 & 29.5 & 100.1 & 33.9 & 317.3 & 40.7 & 158.6 & 6.5 & 839.8 \\
\hline Natunuku & $\mathrm{F} 12$ & 271.0 & 9.2 & 11.0 & 95.0 & 82.8 & 47.3 & 940.0 & 22.5 & 56.9 & 5.4 & 598.4 \\
\hline Natunuku & F13 & 204.3 & 14.5 & 9.3 & 64.2 & 116.7 & 9.2 & 472.4 & 42.8 & 67.5 & 34.9 & 549.1 \\
\hline Natunuku & F14 & 282.5 & 11.3 & 7.5 & 89.3 & 101.5 & 1.1 & 532.0 & 31.4 & 73.9 & 4.5 & 299.2 \\
\hline Natunuku & F15 & 262.8 & 17.6 & 18.7 & 9.9 & 66.2 & 5.7 & 211.8 & 16.9 & 44.2 & 29.7 & 46.3 \\
\hline Natunuku & F16 & 205.8 & 12.2 & 12.4 & 67.7 & 112.9 & 16.0 & 391.1 & 60.6 & 53.9 & 29.7 & 538.1 \\
\hline Kulu Bay & F17 & 573.2 & 15.5 & 13.8 & 643.6 & 66.8 & 2.8 & 177.1 & 28.2 & 49.7 & 4.5 & 326.9 \\
\hline Kulu Bay & F18 & 239.5 & 11.0 & 18.3 & 148.2 & 89.3 & 18.4 & 377.4 & 27.5 & 86.1 & 2.7 & 127.1 \\
\hline Kulu Bay & F19 & 355.5 & 12.8 & 14.7 & 213.3 & 84.1 & 17.9 & 134.2 & 21.4 & 33.8 & 1.2 & 187.6 \\
\hline Kulu Bay & $\mathrm{F} 20$ & 311.6 & 18.6 & 15.3 & 17.0 & 95.9 & 1.3 & 117.6 & 19.1 & 29.5 & 22.7 & 31.1 \\
\hline Kulu Bay & F21 & 348.1 & 16.9 & 13.7 & 28.3 & 45.2 & 7.5 & 129.2 & 22.5 & 46.6 & 0.1 & 57.2 \\
\hline Kulu Bay & $\mathrm{F} 22$ & 205.4 & 30.1 & 19.7 & 48.3 & 84.4 & 4.5 & 291.4 & 11.1 & 58.8 & 1.9 & 158.4 \\
\hline Kulu Bay & $\mathrm{F} 23$ & 157.0 & 7.3 & 7,8 & 46.3 & 80.4 & 5.8 & 282.3 & 28.7 & 50.8 & 1.5 & 356.7 \\
\hline Ugaga Is. & F24 & 273.8 & 437.0 & 129.5 & 46.0 & 68.9 & 2.2 & 140.8 & 14.2 & 33.6 & 0.1 & 92.9 \\
\hline Kulu Bay & $\mathrm{F} 25$ & 278.6 & 65.9 & 26.2 & 145.9 & 83.9 & 27.0 & 676.3 & 26.9 & 87.7 & 3.1 & 361.4 \\
\hline Ma'uke & Cooks1 & 279 & 0 & 54 & 42 & 159 & 27 & 598 & 42 & 347 & 39 & 264 \\
\hline Ma'uke & Cooks2 & 248 & 0 & 19 & 34 & 110 & 20 & 717 & 33 & 241 & 63 & 370 \\
\hline Flake, Area 1 & 15 (TTM-A1) & 221 & 0 & 0 & 7 & 195 & 44 & 710 & 50 & 406 & 44 & 297 \\
\hline Flake, Area 1 & 17 (TTM-A1) & 214 & 0 & 0 & 8 & 191 & 38 & 720 & 50 & 406 & 42 & 330 \\
\hline Flake, Area 3 & 23 (TTM-АЗ) & 209 & 0 & 6 & 15 & 190 & 41 & 721 & 50 & 407 & 44 & 314 \\
\hline Flake, Leone & AN40 & 197 & 0 & 0 & 0 & 197 & 50 & 742 & 51 & 424 & 44 & 326 \\
\hline Flake, Leone & AN41 & 305 & 0 & 41 & 26 & 549 & 28 & 622 & 43 & 350 & 40 & 271 \\
\hline II.2 & Asiapa & 153 & 0 & 17 & 23 & 193 & 41 & 755 & 55 & 451 & 48 & 426 \\
\hline Tutuila & Maupua & 198 & 1 & 36 & 30 & 150 & 342 & 107 & 50 & 473 & 60 & 317 \\
\hline TUT-II.3 & Le'aeno & 247 & 0 & 23 & 25 & 181 & 39 & 764 & 43 & 391 & 47 & 303 \\
\hline Tutuila & Tataga-matau & 210 & 1 & 0 & 5 & 182 & 42 & 708 & 49 & 383 & 49 & 305 \\
\hline Pitcairn & Tautama & 109 & 8 & 1 & 15 & 171 & 39 & 589 & 48 & 417 & 89 & 458 \\
\hline Marquesas & Eiao & 297 & 87 & 100 & 47 & 130 & 18 & 591 & 37 & 306 & 28 & 187 \\
\hline Kaho'olawe & Pu'umoiwi & 345 & 59 & 60 & 75 & 145 & 16 & 396 & 65 & 228 & 17 & 299 \\
\hline Hawai'i & Mauna Kea & 427 & 0 & 30 & 35 & 137 & 30 & 538 & 39 & 314 & 44 & 405 \\
\hline Maui & Haleakala & 38 & 6 & 0 & 8 & 133 & 55 & 1105 & 41 & 412 & 77 & 886 \\
\hline Lana'í & Kapohaku & 304 & 291 & 118 & 103 & 106 & 7 & 357 & 64 & 136 & 10 & 97 \\
\hline o'ahu & Waiahole & 272 & 225 & 123 & 106 & 104 & 10 & 445 & 25 & 167 & 10 & 119 \\
\hline Easter Island & Ovahe & 162 & 1 & 7 & 5 & 154 & 28 & 299 & 74 & 459 & 53 & 260 \\
\hline Ra'iatea & Ra'iatea II & 158 & 8 & 3 & 12 & 118 & 63 & 1882 & 42 & 433 & 74 & 864 \\
\hline Tahiti & Tahinu II & 381 & 1 & 53 & 110 & 114 & 53 & 740 & 34 & 311 & 60 & 587 \\
\hline
\end{tabular}




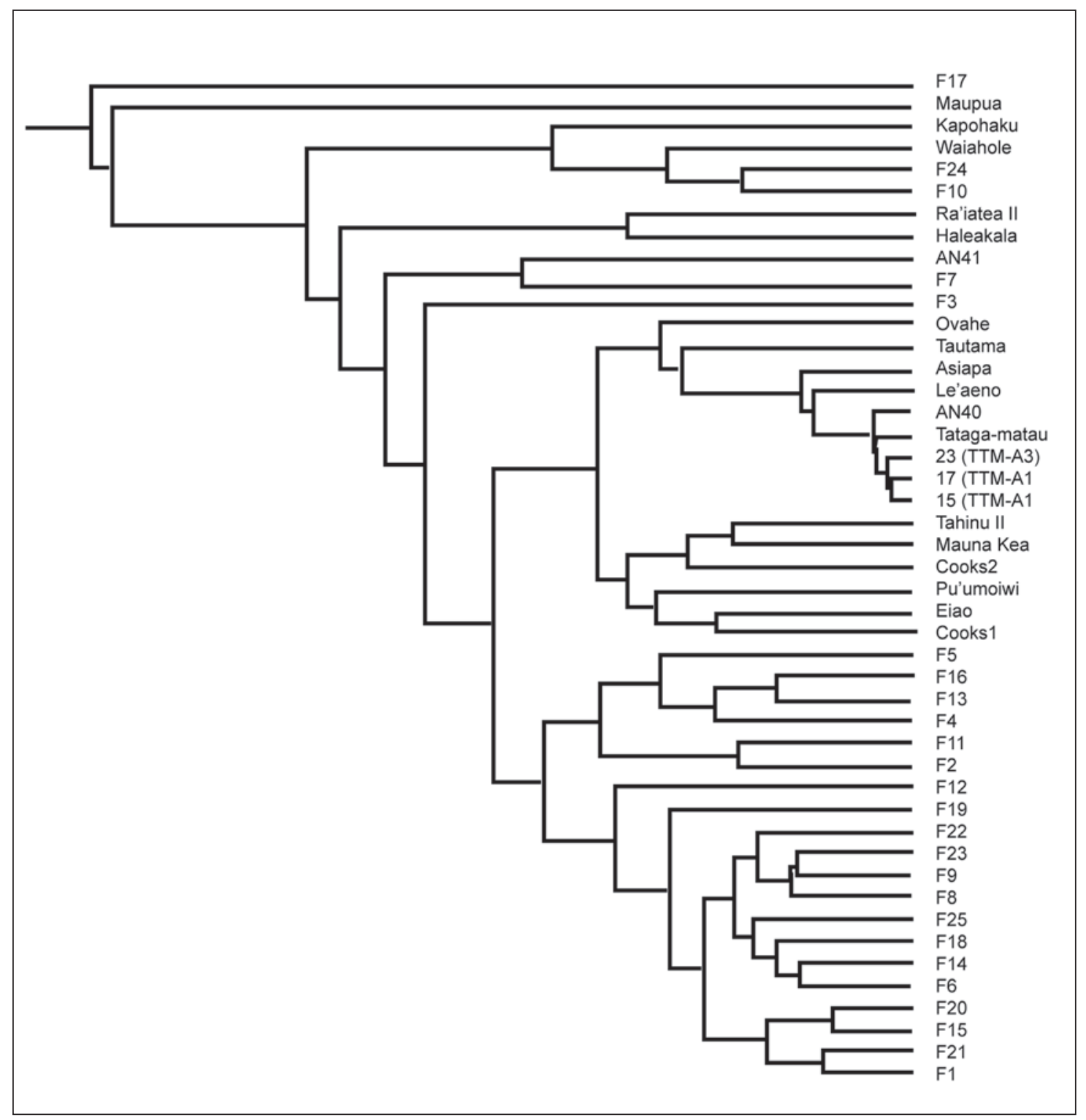

Figure 167. Hierarchical clustering report for trace element analysis of Fiji excavated samples and reference samples.

\section{Adze samples: Conclusion}

Among the small sub samples cut from 25 excavated flakes and adzes, some showed a high degree of weathering which would influence the petrography and chemical make-up. The pieces were successfully analysed for major/minor element oxides using EDXA and for 17 trace elements by ICP-MS. In addition, phosphorus was determined by ICP-AES.

EDXA works best on polished flat specimens, which was the reason for preparing such samples in this project. A comparison of solid versus powdered samples indicates that powdered samples may be successfully analysed and the results normalised to $100 \%$. This method of sample preparation is preferred when minimal damage to an artefact is necessary - for example, in museum specimens, where a sample can be obtained by drilling. Contamination of samples during the sampling and pulverising process is not a great concern for major/minor element oxide determinations. However, trace-element concentrations can be affected by sampling and pulverising processes. 
ICP-MS is an excellent method for the determination of trace-element concentrations because of its sensitivity and small sample size requirements. Most analytical determinations for sourcing studies in the Pacific have been done using XRF. This has limited the number of chemical elements which have been determined and various researchers have selected different element suites, further restricting comparisons. A non-destructive EDXRF method used by Weisler is probably the ideal for museum specimens, but the lack of instrumentation and reduced sample output restricts this technique.

The analyses reveal that some of the samples from the Fiji excavations are closely linked with Best's (1984) samples. A Lakeba adze (AN27) is closely linked with sample F11, but they do not resemble one another petrologically. Lakeba rock (AN24) is closely linked with F3 and F16 and they could be from the same source. Lakeba rock (AN23) is linked to a cluster of excavated samples and some of these may be from the same source, samples that also include AN24.

None of the excavated samples are closely associated with Samoan reference samples. However, no adzes resembling those of known Samoan morphology were found. All of the flakes which were analysed are most likely from local sources.

Closely linked samples which should be considered as coming from three separate sources are F12, F25; F8, F22, F23; and F6, F14. Another pair, F10, F24, with differing petrology, may be from the same source. These closely linked samples indicate inter- and intra-island usage of rock from the same sources. Also, there may be a considerable time depth to this usage.

Trace-element analyses characterised the excavated samples but there were no relevant reference samples from local quarries to carry out sourcing. It is clear from the clustering analyses that none of the artefacts was from Samoa.

Best (1984) and Best et al. (1992) analysed archaeological lithic samples from Fiji and Samoa as well as the wider Pacific. Their interest, after the discovery that basalt adzes could be sourced to the island of Tutuila, has centred on basalt and Samoa to the detriment of Fijian lithics. Other rock types are to be found to the west of the Andesite Line, making sourcing of rocks found in archaeological sites in Fiji more complex. There is little data available except for some initial work by the above authors. 


\section{Appendix: Chemical characterisation of chert artefacts from Fiji}

\section{Geoffrey Clark}

Department of Archaeology and Natural History, The Australian National University

\section{Introduction}

Flake tools made in siliceous rock have been found in numerous archaeological sites in Fiji and such materials might represent prehistoric movement and interaction in the Central Pacific (Green 1996). Crypto-crystalline rocks fracture conchoidally and were commonly used to make expedient sharp-edged artefacts. Primarily composed of silica $\left(\mathrm{SiO}_{2}\right)$, with minor oxides of $\mathrm{Al}$, $\mathrm{Fe}, \mathrm{Ca}, \mathrm{Mn}, \mathrm{Na}, \mathrm{K}$ and $\mathrm{Mg}$, chert develops in different environments often over long periods and varies in its colour, texture and composition. In geology, 'chert' is a term that includes flint, chalcedony, jasper, silicified coral and other crypto-crystalline material. The different colours of chert often reflect the amount and form of minor elements, particularly Fe, which in red 'jasper' is in the form of hematite $\left(\mathrm{Fe}_{2} \mathrm{O}_{3}\right)$, while in yellow chert $\mathrm{Fe}$ is in the form of lepidocrocite $(\mathrm{FeO}(\mathrm{OH}))$. White chert, whether partially or completely translucent, often indicates a low concentration of minor elements. Accidental and purposeful heating as well as weathering can affect the colour, hardness and flaking characteristics of chert (Hatch and Miller 1996).

Ward and Smith (1974) used X-Ray Fluorescence (XRF) to compare the chemical signatures of cherts from the Solomon Islands with those from Australia, New Zealand and New Guinea, and, from a comparison of trace elements, demonstrated the likely transfer of chert from Ulawa to the Reef Santa Cruz Islands. In an important paper, Sheppard (1996:101) summarised the distribution of chert, obsidian and basalt in Near and Remote Oceania and noted that chert had a wide areal extent but a low regional frequency, and was usually not abundant at an individual source. Chert could be divided using petrology into different types based on quartz mineralogy and micro-fossil content and structure, with the possibility that chert from Futuna was taken to Tikopia around ca. $1500 \mathrm{AD}$. Geochemical analyses appeared to reflect the major depositional environment, suggesting that cherts that were formed in comparable geological settings and conditions might have similar chemical signatures.

The diverse geology of the Fiji Islands indicates the existence of numerous chert sources (see Chapter 14), with two sources of jasper and two sources of silicified coral reported from Vaunuabalavu in the Lau Group. Best (1984:415-416) identified a silicified coral source on Vanuabalavu as the likely source of flakes from an early site on Lakeba, which demonstrated the transfer of silicious stone within the Lau Group. A pilot project to examine the chemical composition of chert tools recovered in the EPF excavations was instigated as no geochemical analyses of Fijian chert had been made, and the presence of silicious tools in sites could represent the widespread transfer of crypto-crystalline material in prehistory.

\section{Materials and methods}

Twenty chert tools recovered from EPF excavations were selected for analysis: Votua $(n=12)$, Kulu Bay $(n=4)$, Natunuku $(n=3)$, Ugaga Island $(n=1)$ and Yacata Island $(n=2$, see Clark and Hope 2001). A jasper outcrop was sampled at Tiotio on Vanuabalavu $(n=1)$. Additional chert tools were obtained from existing archaeological collections in Fiji (Sigatoka $n=5$, Natunuku $n=3$, Cikobia $n=2$, Lakeba $n=6$, Totoya $n=4$ ), making a total of 43 samples (Table 90). Chert artefacts from Votua and Sigatoka date to the late-Lapita era, but the dating of chert samples from other sites is uncertain, as at Kulu Bay and Ugaga, where Lapita and post-Lapita artefacts were mixed together, and at Totoya and Yacata, where chert flakes were surface collected. 
Table 90. Chert samples submitted for chemical analysis. FJ09 was not analysed.

\begin{tabular}{|c|c|c|c|}
\hline Lab. No. & Location & Type & Description \\
\hline FJ01 & Mago, Votua, Area 1: 0-10 cm & core & Red banded fine-grained material, pitted with thin veins of grey-blue and brown. \\
\hline $\mathrm{FJ} 02$ & Mago, Votua, Area 1: surface & core & White fine-grained with pale yellow areas and grey veined. \\
\hline $\mathrm{FJ} 03$ & Mago, Votua, Area 1: surface & core & Red banded fine-grained and pitted with grey-blue and brown vacuoles. \\
\hline $\mathrm{FJ} 04$ & Mago, Votua, Area 1: 0-10 cm & flake & Yellow-brown banded and fine-grained. \\
\hline FJ05 & Mago, Votua, Area 1: $20-30 \mathrm{~cm}$ & flake & Dark red fine-grained homogeneous material. \\
\hline $\mathrm{FJ} 06$ & Mago, Votua, Area 2: 0-10 cm & flake & Red with micro-layering, fine-grained with a thin lens of brick red material in section. \\
\hline $\mathrm{FJ} 07$ & Mago, Votua, Area 2: 30-40 cm & flake & $\begin{array}{l}\text { Dark red fine-grained surrounding a light orange-red area } 4 \mathrm{~mm}^{2} \text {. Cortex in cross section has a thin } \\
\text { white covering. }\end{array}$ \\
\hline FJ08 & Mago, Votua, Area 2: 0-30 cm & flake & Yellow-brown fine-grained with diffuse patches of grey-black, possible cortex on one face. \\
\hline $\mathrm{FJ} 09$ & Mago, Votua, Area 2: $30-40 \mathrm{~cm}$ & flake & Brown fine-grained material with small vacuoles. \\
\hline FJ10 & Mago, Votua, Area 2: $30-40 \mathrm{~cm}$ & flake & Dark red fine-grained with patches of mottled pink and a few small vacuoles. \\
\hline FJ11 & Mago, Votua, Area 2: 0-10 cm & flake & Brown with thin branches of red-brown and diffuse patches of quartz. \\
\hline $\mathrm{FJ} 12$ & Mago, Votua, Area 2: 10-20 cm & flake & Mottled yellow brown and a vein of red penetrating $3 \mathrm{~mm}$ from cortex. \\
\hline FJ13 & Viti Levu, Sigatoka, 45A, Y/2/2 & flake & Pale white with diffuse inclusions of dark red. White cortex on one face. \\
\hline FJ14 & Viti Levu, Sigatoka, 45A, Y/2/4 & flake & Yellow with red patches near cortex. Small crystals on thin cortex layer. \\
\hline FJ15 & Viti Levu, Sigatoka, 45A, S & flake & $\begin{array}{l}\text { White fine-grained material with an area of yellow and red on one edge. Numerous small grey } \\
\text { vacuoles. }\end{array}$ \\
\hline FJ16 & Viti Levu, Sigatoka, 45A, Y/2/4 & flake & Yellow-white coarse-grained and veins of grey-green. \\
\hline FJ17 & Viti Levu, Sigatoka, 45A, Z/2/1 & flake & White fine-banded material with stained patches of yellow. \\
\hline FJ18 & Cikobia, CIK-06B: 130-140 cm & flake/core & Brown fine-grained and banded material with veins of quartz and small grey vacuoles. \\
\hline FJ19 & Cikobia, CIK-06D: 80-90 cm & flake & Dense dark red material with small pinkish pits near cortex and a few interior grey-blue vacuoles. \\
\hline $\mathrm{FJ} 20$ & Viti Levu, Natunuku, Tr. 3: Layer 2A & flake & White mottled with grey-to-yellow quartz. No visible banding or vacuoles. \\
\hline FJ21 & Viti Levu, Natunuku, Tr. 3: 30-40 cm & flake & $\begin{array}{l}\text { Red glassy material with a coarse-grained inclusion of ?red-black glass. Near the edge the material is } \\
\text { coarse-grained with particles of white, red and ?black. }\end{array}$ \\
\hline $\mathrm{FJ} 22$ & Viti Levu, Natunuku, surface. FJM & flake & $\begin{array}{l}\text { White fine-grained and banded material stained with pale yellow-brown. Sample had a small oyster } \\
\text { growing on surface. }\end{array}$ \\
\hline $\mathrm{FJ} 23$ & Viti Levu, Natunuku, surface. FJM & flake & Pink-red quartz coarse material with a plate-like structure. \\
\hline $\mathrm{FJ} 24$ & Viti Levu, Natunuku, Tr. 3: 50-60 cm & flake & Dark red dense material with veins of purple-red and numerous grey-blue vacuoles. \\
\hline $\mathrm{FJ} 25$ & Viti Levu, Natunuku, surface. FJM & flake & Orange-brown cortex. Interior has blocky grey-white inclusions with coarse and irregular banding. \\
\hline $\mathrm{FJ} 26$ & Beqa, Kulu, C10: $30-50 \mathrm{~cm}$ & flake & $\begin{array}{l}\text { White coarse-grained material with very small patches of black and yellow-brown. No banding } \\
\text { present. }\end{array}$ \\
\hline FJ27 & Beqa, Kulu, C10: 30-50 cm & flake & White-grey material with diffuse white patches and inclusions. Pale yellow towards edge. \\
\hline $\mathrm{FJ} 28$ & Beqa, Kulu, C11: $30-40 \mathrm{~cm}$ & flake & $\begin{array}{l}\text { Pink-white material with round inclusions of red-orange and angular white particles. Vacuoles and } \\
\text { possible micro-fossils. }\end{array}$ \\
\hline FJ29 & Beqa, Kulu, C10: 0-30 cm & flake & White homogeneous material lacking vacuoles or coloured inclusions. \\
\hline $\mathrm{FJ} 30$ & Beqa, Ugaga, P9: $30-40 \mathrm{~cm}$ & flake & Interior has angular fragments of quartz surrounded by irregular areas of yellow and red. \\
\hline FJ31 & Lakeba, 196-12-B-1(1) & flake/drill bit & White homogeneous fine-grained material. \\
\hline $\mathrm{FJ} 32$ & Lakeba, 101/7/47(16A) & flake & Irregular coarse areas of pinkish-red and brown. \\
\hline FJ33 & Lakeba, 196-B-B-3(2) & flake & White course-grained quartz. \\
\hline $\mathrm{FJ} 34$ & Lakeba, 196-16-B-1(1) & flake & Mottled coarse white and grey-brown with possible micro-fossils. \\
\hline FJ35 & Lakeba, 196-16-B-3(8) & flake & Dark red fine-grained and homogeneous material. \\
\hline $\mathrm{FJ} 36$ & Lakeba, 196-23-B14 & flake & Dark red fine-grained with micro-vacuoles and mottled with brick red. \\
\hline FJ37 & Yacata, Natuiwaqa, TP1: 0-30 cm & flake & Dark brown fine-grained material. \\
\hline $\mathrm{FJ} 38$ & Yacata, $200 \mathrm{~m}$ southeast of village & flake & Brick-red interior intruded by crystal-filled vacuoles and dark brown patches. \\
\hline $\mathrm{FJ} 39$ & Vanuabalavu, Tiotio & cobble & Dark red, fine-grained homogeneous material with very small vacuoles. \\
\hline FJ42 & Totoya, Jigojigo, T031/43/32 & flake & Dark red, fine-grained homogeneous material with very small vacuoles. Thin veins of blue ?quartz. \\
\hline FJ43 & Totoya, Keteira 1, T031/46 & flake & Interior crystal-filled vacuoles surrounded by irregular and coarse patches of pink and red material. \\
\hline FJ44 & Totoya, Waroka 3 & flake & Dark red fine-grained material with irregular pink and white streaks. \\
\hline FJ45 & Totoya, Udu, T031/1/2 & flake & Mottled grey-yellow coarse material with small black grains and partially absorbed lathe structures. \\
\hline
\end{tabular}


Chert samples were cut with a hydraulic diamond wire saw with the wire-cut surface analysed with proton and gamma induced X-Ray emissions (PIXIE/PIGME) at the ANSTO 3 $\mathrm{MV}$ van de Graff accelerator at Lucas Heights. Elements measured in ppm were F, Na, Al, Si, K, $\mathrm{Ca}, \mathrm{Ti}, \mathrm{Cr}, \mathrm{Mn}, \mathrm{Fe}, \mathrm{Zn}, \mathrm{Rb}, \mathrm{Sr}, \mathrm{Y}, \mathrm{Zr}, \mathrm{Nb}$ and Pb (Table 91). Sample FJ09 from Votua was too small to examine, leaving 42 analysed samples. Following the geochemical study, chert sections were scanned at 4800 dpi to facilitate the description of colour and texture (Table 90), and to check whether the area sampled by the proton beam - visible in most sample scans as a grey or brown circle - included any voids or anomalies that might affect element concentrations. Element values were $\log 10$ transformed, with individual element values checked against sample colour to identify elements that were highly correlated with Fe. Associated with 'red' iron-rich chert samples were $\mathrm{Pb}, \mathrm{Zn}, \mathrm{Ti}, \mathrm{Rb}, \mathrm{F}, \mathrm{Ca}, \mathrm{Cr}$ and $\mathrm{Mn}$, while $\mathrm{Al}, \mathrm{Na}, \mathrm{K}, \mathrm{Sr}, \mathrm{Y}, \mathrm{Nb}$ and $\mathrm{Zr}$ were not strongly correlated with Fe. SPSS Version 13 software was used to perform two hierarchical cluster analyses (between-groups linkage, squared Euclidean distance).

The first HCA used nine iron-correlated elements in the red chert samples (Fe, $\mathrm{Pb}, \mathrm{Zn}, \mathrm{Ti}$, $\mathrm{Rb}, \mathrm{F}, \mathrm{Ca}, \mathrm{Cr}, \mathrm{Mn}$ ), as colour is a common criterion that is used to group archaeological chert artefacts, and similar-coloured chert tools at different sites could result from the exploitation of a particular source. For red 'jasper' artefacts found in the Lau Group this was especially plausible as there were two known sources of jasper on Vanuabalavu, and artefacts made in red chert were found at the Votua Lapita site on nearby Mago Island. A second HCA was run with remaining elements that were not correlated with Fe. This was to investigate the geochemical variability in samples once the elements largely responsible for sample colour had been removed.

\section{Analysis results}

All samples were composed of a high proportion of $\mathrm{Si}(75.7 \%-99.9 \%)$, with variable amounts of Fe, ranging from $0.01 \%$ to $23.4 \%$, reflecting colour variation between red, white and variegated cherts. Trace elements were extremely low for $\mathrm{Sr}, \mathrm{Y}, \mathrm{Zr}$ and Nb and slightly higher for F, Ca, K and $\mathrm{Cr}$ (Table 91).

The HCA dendrogram of the Fe-correlated elements contains two main clusters (Figure 168). The top cluster contains the majority of chert from archaeological sites in west Fiji, such as Sigatoka, Natunuku and Kulu, with a few samples from east Fiji (Totoya, Votua, Lakeba). These samples are low in $\mathrm{Fe}$, as indicated by their white-to-yellow colour, although two artefacts of reddish chert from Natunuku (FJ21, FJ24) were also placed in the cluster. Most of the whiteyellow samples in the upper cluster were fine-grained and relatively homogeneous, in contrast to six samples forming a separate sub-branch of the lower cluster (FJ16, FJ25, FJ28, FJ30, FJ26, FJ43). These cherts were coarse-grained and heterogeneous with diffuse coloured areas, often with veining and vacuoles. The lower branch of the base cluster was dominated by red chert from the Lau Group and Cikobia Island, north of Udu Point on Vanua Levu, including a sample from the Tiotio outcrop on Vanuabalavu. Individual Votua artefacts were found to be similar to those from Totoya (FJ01 with FJ42), Lakeba (FJ06 with FJ36), and Yacata (FJ11 with FJ37). The Tiotio chert (FJ39) grouped with two artefacts from Lakeba and Votua (FJ10 and FJ35). These samples were similar to one another and were dark red and fine-grained and had only a few small vacuoles.

The second HCA examined elements $\mathrm{Al}, \mathrm{Na}, \mathrm{K}, \mathrm{Sr}, \mathrm{Y}, \mathrm{Nb}$ and $\mathrm{Zr}$ that were not strongly correlated with sample colour (Figure 169). Such elements might represent the origin of a chert with greater reliability than elements responsible for sample colour, particularly if the same source of crypto-crystalline material contained chert of different colours. There is greater variation in 
Table 91. Fijian chert element analysis (ppm).

\begin{tabular}{|c|c|c|c|c|c|c|c|c|c|c|c|c|c|c|c|c|c|c|}
\hline Sample & Location & $F$ & $\mathrm{Na}$ & Al & $\mathrm{Si}$ & K & $\mathrm{Ca}$ & $\mathrm{Ti}$ & $\mathrm{Cr}$ & $\mathrm{Mn}$ & $\mathrm{Fe}$ & $\mathrm{Zn}$ & $\mathbf{R b}$ & $\mathrm{Sr}$ & $Y$ & $\mathrm{Zr}$ & $\mathrm{Nb}$ & $\mathrm{Pb}$ \\
\hline FJ01 & Votua & 5.6 & 272.4 & 155.3 & 585084 & 131 & 102 & 151 & 549 & 0 & 43956 & 2 & 2 & 2 & 0 & 2 & 1 & 40 \\
\hline $\mathrm{FJ02}$ & Votua & 4 & 79.1 & - & 573976 & 185 & 102 & 0 & 41 & 0 & 123 & 4 & 0 & 1 & 1 & 1 & 2 & 0 \\
\hline $\mathrm{FJ03}$ & Votua & 6.6 & 90.2 & - & 580546 & 149 & 183 & 230 & 104 & 139 & 68942 & 16 & 2 & 0 & 0 & 2 & 2 & 86 \\
\hline FJ04 & Votua & 7.3 & 217 & - & 556984 & 461 & 302 & 216 & 894 & 467 & 69134 & 22 & 4 & 0 & 0 & 0 & 2 & 97 \\
\hline FJ05 & Votua & 292.6 & 219.9 & - & 515240 & 167 & 12265 & 423 & 1778 & 268 & 133434 & 28 & 26 & 8 & 0 & 0 & 4 & 130 \\
\hline FJ06 & Votua & 8.2 & 241 & - & 569991 & 179 & 365 & 309 & 1165 & 0 & 97621 & 18 & 0 & 0 & 0 & 2 & 0 & 60 \\
\hline FJ07 & Votua & 60.5 & 276.1 & 136.9 & 511404 & 79 & 2586 & 480 & 1760 & 255 & 158406 & 107 & 7 & 3 & 0 & 5 & 3 & 150 \\
\hline FJ08 & Votua & 6.2 & 503.9 & 532 & 547908 & 690 & 394 & 89 & 465 & 1068 & 37072 & 8 & 0 & 5 & 0 & 1 & 1 & 12 \\
\hline FJ10 & Votua & 29.2 & 268.9 & - & 523852 & 81 & 2006 & 292 & 17 & 99 & 105730 & 11 & 6 & 5 & 0 & 4 & 1 & 77 \\
\hline FJ11 & Votua & 3.1 & 300.5 & - & 564198 & 495 & 123 & 25 & 67 & 209 & 11213 & 4 & 0 & 1 & 1 & 1 & 1 & 2 \\
\hline FJ12 & Votua & 3.3 & 183.9 & - & 553315 & 308 & 109 & 0 & 82 & 30 & 4530 & 3 & 1 & 1 & 1 & 1 & 1 & 2 \\
\hline FJ13 & Sigatoka & 3.5 & 146.4 & 135.6 & 561059 & 152 & 249 & 0 & 120 & 32 & 112 & 1 & 0 & 1 & 0 & 0 & 1 & 0 \\
\hline FJ14 & Sigatoka & 2.6 & 182 & 172.2 & 568646 & 116 & 157 & 0 & 92 & 0 & 268 & 0 & 0 & 2 & 0 & 0 & 1 & 0 \\
\hline FJ15 & Sigatoka & 2.6 & 955.8 & 577.1 & 560531 & 346 & 63 & 0 & 9 & 6 & 337 & 0 & 0 & 1 & 0 & 1 & 0 & 1 \\
\hline FJ16 & Sigatoka & 10.5 & 725.4 & 3277.1 & 569699 & 735 & 957 & 171 & 65 & 22 & 2454 & 5 & 0 & 7 & 2 & 2 & 1 & 0 \\
\hline F117 & Sigatoka & 2.6 & 376.5 & 518.4 & 582253 & 376 & 143 & 0 & 76 & 5 & 81 & 0 & 1 & 1 & 1 & 1 & 1 & 2 \\
\hline FJ18 & Cikobia & 5.7 & 125.5 & 248 & 541222 & 216 & 18265 & 182 & 458 & 504 & 53409 & 7 & 5 & 4 & 0 & 1 & 0 & 43 \\
\hline FJ19 & Cikobia & 4.5 & 101 & - & 574904 & 142 & 235 & 90 & 433 & 249 & 30400 & 6 & 2 & 2 & 0 & 2 & 0 & 20 \\
\hline $\mathrm{FJ} 20$ & Natunuku & 3.2 & 106.8 & 204.5 & 581342 & 102 & 141 & 0 & 0 & 3 & 224 & 1 & 1 & 2 & 0 & 1 & 1 & 1 \\
\hline FJ21 & Natunuku & 4.8 & 24.8 & - & 599117 & 126 & 20684 & 0 & 127 & 4 & 663 & 2 & 0 & 12 & 0 & 1 & 1 & 1 \\
\hline $\mathrm{FJ} 22$ & Natunuku & 2.6 & 1203.7 & 320.8 & 574729 & 314 & 0 & 0 & 34 & 0 & 61 & 2 & 1 & 0 & 0 & 2 & 3 & 0 \\
\hline $\mathrm{F} / 23$ & Natunuku & 2.8 & 332.7 & 343.8 & 562690 & 335 & 97 & 0 & 107 & 8 & 330 & 2 & 1 & 1 & 1 & 2 & 2 & 0 \\
\hline FJ24 & Natunuku & 4.3 & 230.6 & - & 565118 & 240 & 0 & 0 & 354 & 50 & 25036 & & 1 & 0 & 0 & 0 & 3 & 17 \\
\hline $\mathrm{FJ} 25$ & Natunuku & 43.2 & 1558.3 & 3677.3 & 556349 & 1152 & 1334 & 188 & 122 & 11 & 682 & 1 & 0 & 13 & 2 & 6 & 0 & 1 \\
\hline $\mathrm{FJ} 26$ & Kulu & 11.4 & 15.9 & 204.2 & 571314 & 16 & 106 & 1574 & 9 & 1 & 148 & 2 & 1 & 2 & 1 & 97 & 1 & 5 \\
\hline FJ27 & Kulu & 4.4 & 112.5 & - & 566835 & 49 & 67 & 0 & 80 & 0 & 188 & 0 & 0 & 5 & 3 & 4 & 4 & 0 \\
\hline FJ28 & Kulu & 3.6 & 186.5 & 188 & 564416 & 139 & 226 & 3351 & 161 & 6 & 296 & 1 & 2 & 3 & 1 & 4 & 3 & 4 \\
\hline FJ29 & Kulu & 1.5 & 167.5 & 357.5 & 575126 & 214 & 261 & 9 & 44 & 12 & 156 & 4 & 1 & 3 & 0 & 2 & 2 & 1 \\
\hline $\mathrm{FJ} 30$ & Ugaga & 4.1 & 40.6 & 132.7 & 566088 & 224 & 107 & 6322 & 120 & 0 & 4003 & 2 & 0 & 2 & 2 & 10 & 3 & 6 \\
\hline FJ31 & Lakeba & 3.3 & 192.7 & 322.3 & 599963 & 210 & 464 & 20 & 158 & 8 & 356 & 7 & 1 & 2 & 1 & 2 & 2 & 7 \\
\hline $\mathrm{FJ} 32$ & Lakeba & 5.3 & 150.5 & 246.6 & 564536 & 528 & 212 & 149 & 247 & 572 & 30726 & 10 & 2 & 3 & 0 & 0 & 1 & 18 \\
\hline $\mathrm{FJ} 33$ & Lakeba & 1.8 & 79.3 & - & 568402 & 141 & 128 & 0 & 216 & 4 & 186 & 2 & 2 & 2 & 1 & 1 & 2 & 1 \\
\hline FJ34 & Lakeba & 12.3 & 104.4 & - & 570234 & 90 & 133 & 13 & 86 & 12 & 230 & 0 & 1 & 2 & 2 & 0 & 1 & 2 \\
\hline $\mathrm{FJ} 35$ & Lakeba & 6.2 & 237.1 & 221.1 & 547460 & 187 & 1027 & 402 & 100 & 43 & 50980 & 8 & 0 & 5 & 4 & 2 & 3 & 13 \\
\hline FJ36 & Lakeba & 7.3 & 125.3 & 223.3 & 573053 & 128 & 110 & 321 & 1181 & 0 & 109461 & 7 & 1 & 0 & 0 & 6 & 5 & 188 \\
\hline FJ37 & Yacata & 2.3 & 38 & - & 561106 & 505 & 345 & 28 & 208 & 731 & 15833 & 4 & 2 & 3 & 2 & 1 & 0 & 4 \\
\hline FJ38 & Yacata & 50.4 & 571.2 & 3790.1 & 541650 & 3142 & 261 & 1051 & 1433 & 119 & 106580 & 11 & 18 & 3 & 0 & 11 & 3 & 130 \\
\hline FJ39 & Tiotio & 8.8 & 261.5 & 3772.6 & 545718 & 1392 & 583 & 298 & 58 & 5 & 22287 & 1 & 3 & 8 & 3 & 8 & 3 & 17 \\
\hline FJ42 & Totoya & 6.1 & 60.6 & 43.5 & 557957 & 10 & 157 & 129 & 588 & 0 & 45740 & 2 & 2 & 0 & 0 & 12 & 1 & 15 \\
\hline $\mathrm{FJ} 43$ & Totoya & 5.9 & 32.6 & 58.8 & 547170 & 91 & 233 & 4769 & 0 & 28 & 3831 & 3 & 0 & 2 & 2 & 16 & 2 & 5 \\
\hline FJ44 & Totoya & 5 & 216.9 & - & 563570 & 265 & 138 & 0 & 149 & 28 & 5258 & 2 & 0 & 2 & 2 & 0 & 2 & 0 \\
\hline FJ45 & Totoya & 9.7 & 141.4 & 177.2 & 586752 & 174 & 154 & 9712 & 553 & 0 & 66733 & 6 & 0 & 26 & 0 & 44 & 1 & 44 \\
\hline
\end{tabular}




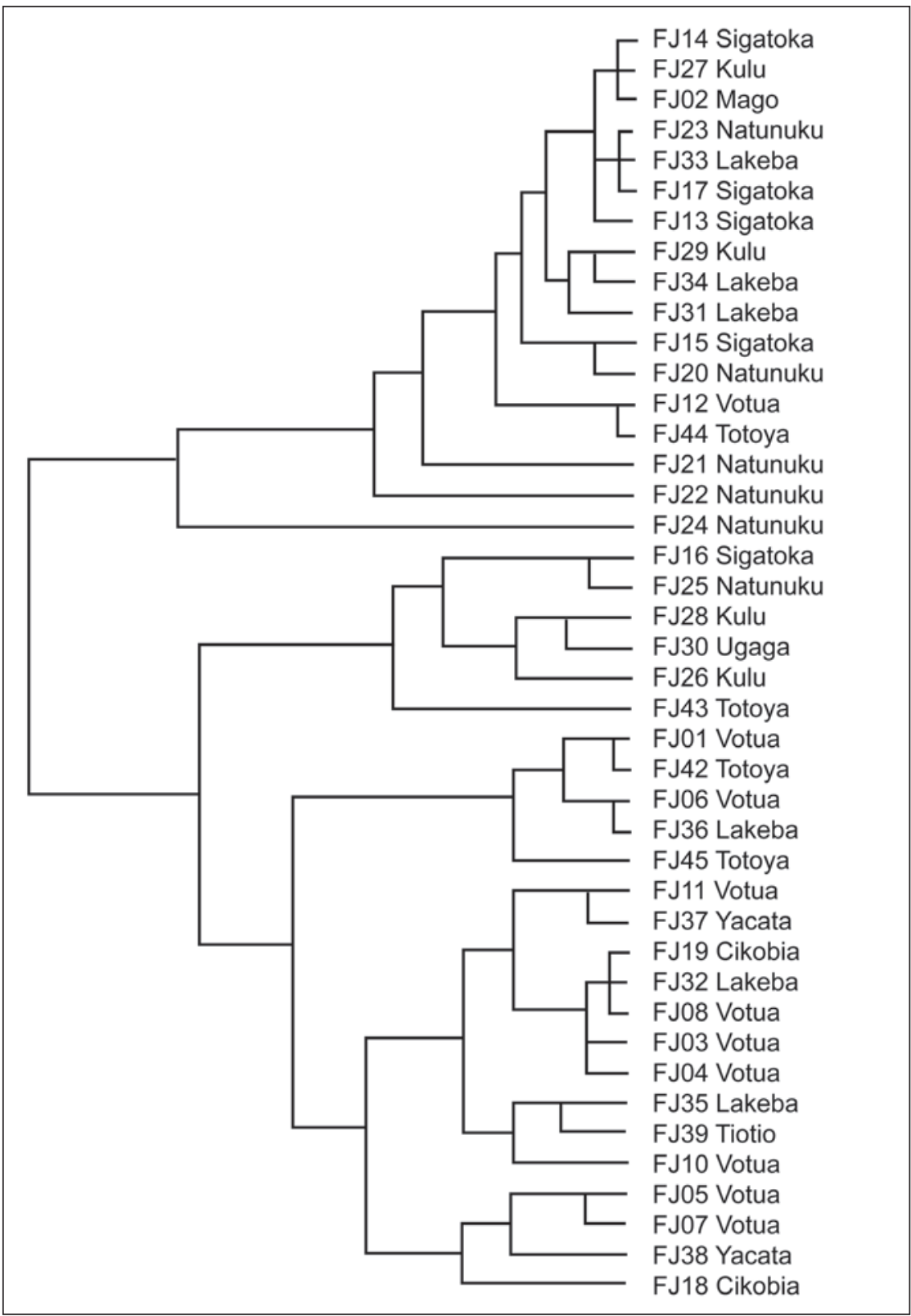

Figure 168. Hierarchical clustering report for chert samples using Fecorrelated elements.

the distribution of samples in the HCA, with Votua artefacts in the major clusters. The ability to discriminate chert with the seven minor and trace elements does not appear great, as the Tiotio source (FJ39) did not group with any of the Votua artefacts, despite Vanuabalavu being the closest known source of red chert to Mago Island. However, the majority of cherts from Sigatoka were in the top cluster, while three artefacts from Totoya were grouped together in a subcluster (FJ42, FJ43, FJ45), indicating that the artefact groupings are not entirely arbitrary.

\section{Conclusions}

Chert is a heterogenous material compared with some basalts, and particularly obsidians, which form by the rapid cooling of a relatively homogeneous magma fluid (Lyons et al. 2003). Attribution of an artefact to a particular source is further complicated by the number of potential sources in the Central Pacific, as chert can be formed by diagenesis in limestone environments as nodules, or be deposited in thin or thick beds, especially in geosynclinal deposits that have been uplifted. Potential sources of chert have been recorded on Viti Levu (Hunt 1979), Vanua 


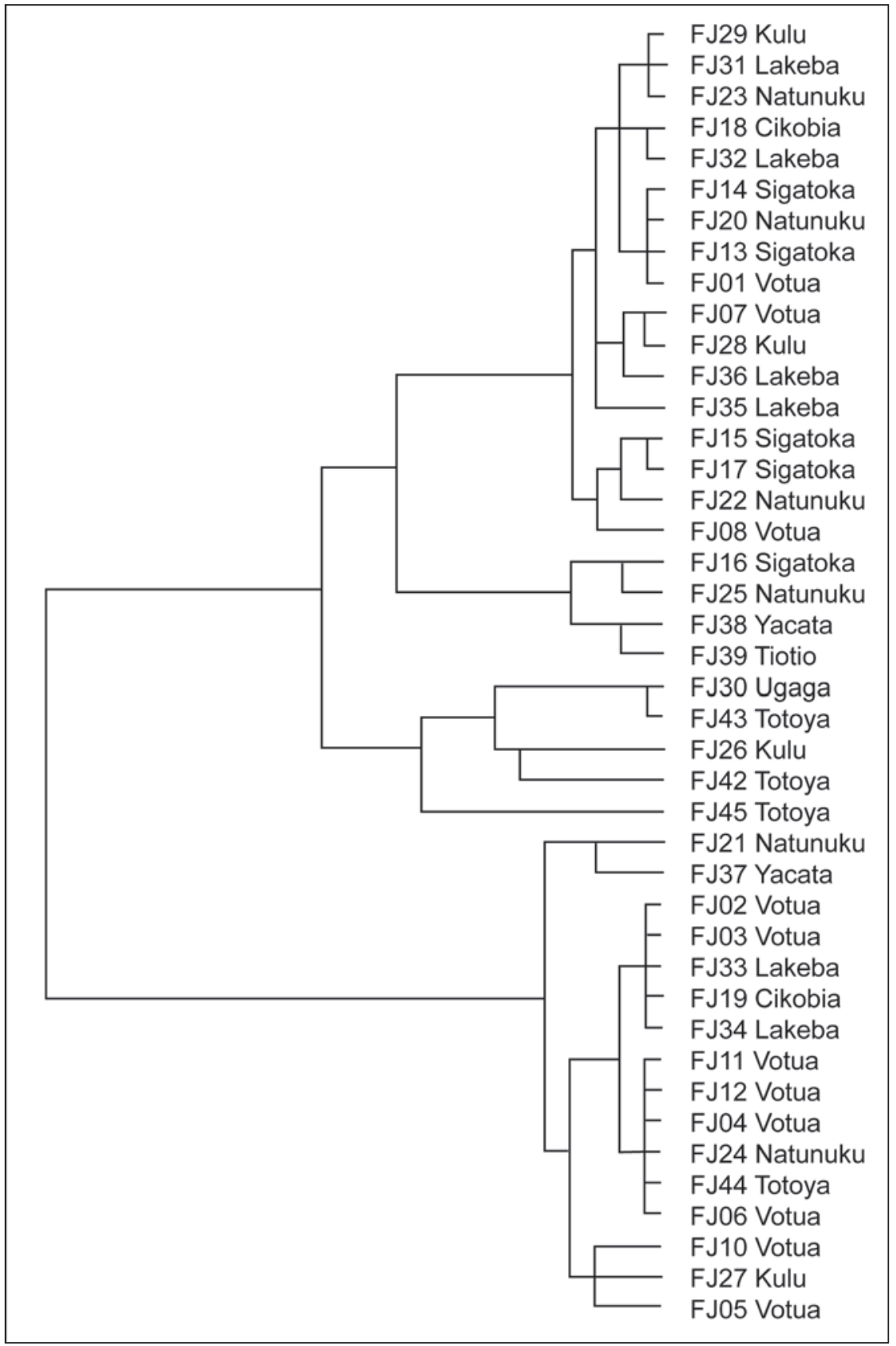

Figure 169. Hierarchical clustering report for chert samples using elements not strongly correlated with sample colour (Al, Na, K, Sr, $\mathrm{Y}$, $\mathrm{Nb}, \mathrm{Zr})$.

Levu and Vanuabalavu, but many more must be present considering the complicated geology and number of islands in the Fiji archipelago.

Chemical analysis of chert artefacts revealed a group of elements strongly correlated with $\mathrm{Fe}$, which in different forms is the main contributor to chert colour. As expected, these elements in a HCA grouped samples by colour, but the analysis also correctly sorted the majority of samples by texture. The similar visual and textural properties of chert were reinforced by the chemical results that placed chert from an outcrop on Vanuabalavu with artefacts from the Votua Lapita site. Results also indicated that a white-yellow chert found at Natunuku and Sigatoka may be from the same source (probably Viti Levu), and chert from this source might also have been taken to Beqa Island and Lakeba. Red and yellow chert artefacts from Votua, Lakeba, Yacata and Totoya are likely to originate from a source in the Lau Group and may have been taken as far afield as Cikobia, while the red chert appears to be from a different source. It is 
interesting that a red chert (presumed to be local) circulates mainly in the Lau Group and outer islands, while on Viti Levu, a white chert-chalcedony may have been distributed as far as the Suva area in late prehistory, as Hunt (1979:38) reports that flakes from a ring-ditch overlooking the Samabula River were of the same material as flakes found at Sigatoka. A number of early sites contain chert artefacts, but the temporal association of crypto-crystalline tools with Lapita pottery is unclear due to site disturbance, except at Votua where chert artefacts are numerous. On Lakeba, silicified materials were certainly present in Lapita-age deposits and are common at the Ulunikoro (Site 47) fortification, dating to about AD 1100 (Best 1984:492-493).

Minor and trace elements for chert artefacts did not produce coherent geographic clusters, and several trace elements were present at low concentrations, meaning that they have a limited capacity to confidently differentiate prehistoric artefacts. Chert was almost certainly transported through the Fiji Islands in prehistory and future work should concentrate on establishing the chemical and petrological variation in the known chert sources so that archaeological artefacts can be identified to a source with greater confidence.

\section{References}

Allen, M.S. and Johnson, K.T.M. 1997. Tracking ancient patterns of interaction: Recent geochemical studies in the southern Cook Islands. In: Weisler, M.I. (ed), Prehistoric long-distance interaction in Oceania: An interdisciplinary approach, pp. 111-113. New Zealand Archaeological Association Monograph 21, NZAA, Auckland.

Anderson, A., Ambrose, W., Leach, F. and Weisler, M. 1997. Material sources of basalt and obsidian artefacts from a prehistoric settlement site on Norfolk Island, South Pacific. Archaeology in Oceania 32: 39-46.

Ayres, W.S., Goles, G.B. and Beardsley, F.R. 1997. Provenance study of lithic materials in Micronesia. In: Weisler, M.I. (ed), Prehistoric long-distance interaction in Oceania, pp. 53-67. New Zealand Archaeological Association Monograph 21.

Best, S. 1984. Lakeba: The prehistory of a Fijian island. Unpublished PhD thesis, University of Auckland.

Best, S. 1989. Lakeba: The prehistory of a Fijian island. University Microfilms, Ann Arbor, Michigan.

Best, S., Sheppard, P. Green, R. and Parker, R. 1992. Necromancing the stone: archaeologists and adzes in Samoa. Journal of the Polynesian Society 101(1): 45-85.

Buist, A. 1969. Field archaeology on Savai'i. In: Green, R. and Davidson, J. (eds), Archaeology in Western Samoa 1: 34-68. Bulletin of the Auckland Institute and Museum 6, Auckland.

Clark, G and Hope, G. 2001. Archaeological and palaeoenvironmental investigations on Yacata Island, northern Lau, Fiji. Domodomo 13: 29-47.

Clark, J.T., Wright, E. and Herdrich, D.J. 1997. Interactions within and beyond the Samoan archipelago: Evidence from basaltic rock geochemistry. In: Weisler, M.I. (ed), Prehistoric longdistance interaction in Oceania: An interdisciplinary approach. New Zealand Archaeological Association Monograph 21, NZAA, Auckland.

Cleghorn, P.L., Dye, T., Weisler, M. and Sinton, J. 1985. A preliminary petrographic study of Hawaiian stone adze quarries. Journal of the Polynesian Society 94: 235-251.

Dickinson, W.R. and Shutler, R. 1979. Petrography of sand tempers in Pacific Islands potsherds: Summary. Geological Society of America Bulletin 90: 993-995.

Dye, T.S., Weisler, M.I. and Riford, M. 1985. Adz quarries on Moloka’i and Oahu, Hawaiian Islands. 
Report 093085 on file, Department of Anthropology. Bernice P. Bishop Museum, Honolulu. Emory, K.P. 1975. Material culture of the Tuamotu Archipelago. Pacific Anthropological Records 22. Bernice P. Bishop Museum, Honolulu.

Goodhew, P.J. and Humphreys, F.J. 1988. Electron microscopy and analysis. Taylor and Francis, London. Green, R.C. 1974. Review of portable artifacts from Western Samoa. In: Green, R.C. and Davidson, J. (eds), Archaeology. in Western Samoa 2: 245 275. Bulletin of the Auckland Institute and Museum 7, Auckland:

Green, R.C. 1996. Prehistoric transfers of portable items during the Lapita horizon in Remote Oceania: A review. Bulletin of the Indo-Pacific Prehistory Association 15: 119-130.

Green, T. 1984. Appendix I: Petrologic evaluation of artifact material from Norfolk Island, In Specht, J. (ed), The Prehistoric Archaeology of Norfolk Island: 53-56. Pacific Anthropological Records 34. Bishop Museum, Honolulu.

Green, R.C. and Davidson, J. (eds). 1969. Archaeology in Western Samoa, Volume 1. Bulletin of the Auckland Institute and Museum 7.

Hatch, J.W. and Miller, P.E. 1996. Procurement, tool production, and sourcing research at the Vera Cruz jasper quarry in Pennsylvania. Journal of Field Archaeology 12: 219-230.

Hunt, C. 1979. A flaked stone industry from Fiji. The Artefact 4: 37-39.

Jarvis, K.E., Gray, A.L. and Houk, R.S. 1992. Sample preparation for ICP-MS, Chapter 7. Handbook of inductively coupled plasma mass spectrometry. Chapman and Hall, London.

Kirch, P.V. 1975. Excavation at sites A1-3 and A1-4: Early settlement and ecology in Halawa Valley. In: Kirch, P.V. and Kelly, M. (eds), Prehistory and Ecology in a Windward Hawaiian Valley: Halawa Valley, Moloka'i: 17-70. Pacific Anthropological Records 24. Bishop Museum, Honolulu.

Kirch, P.V. 1988. Niuatoputapu: The Prehistory of a Polynesian Chiefdom. Thomas Burke Memonal Washington Stale Museum Monograph 5. Seattle.

Leach, H. and Witter, D. 1987. Tataga-matau "rediscovered". New Zealand Journal of Archaeology 9: $33-54$.

Leach, H. and Witter, D. 1990. Further investigations at the Tataga-matau site, American Samoa. New Zealand Journal of Archaeology 12: 51-83.

Lyons, W.H., Glascock, M.D. and Mehringer, Jr. 2003. Silica from sources to site: Ultraviolet fluorescence and trace elements identify cherts from Lost Dune, southeastern Oregon, USA. Journal of Archaeological Science 30: 1139-1159.

Rapp, G., Jr. 1985. The provenance of artifactual raw materials. In: Rapp, G. Jr. and Gifford, J.A. (eds), Archaeological geology. Yale University Press, New Haven.

Romesburg H.C. 1984. Cluster analysis for researchers. Lifetime Learning Publications, Belmont, California.

Rolett, B.V., Conte, E., Pearthree, E. and Sinton, J.M. 1997. Marquesan voyaging: archaeometric evidence for inter-island contact. In: Weisler, M.I. (ed), Prehistoric long-distance interaction in Oceania: An interdisciplinary approach. New Zealand Archaeological Association Monograph 21, NZAA, Auckland.

Rubinson, K.A. 1987. Chemical analysis. Little, Brown and Company, Boston.

Sheppard, P.J. 1996. Hard rock: Archaeological implications of chert sourcing in Near and Remote Oceania. In: Davidson, J.M., Irwin, G., Leach, B.F., Pawley, A. and Brown, D. (eds), Oceanic Culture History: Essays in honour of Roger Green, pp. 99-115. New Zealand Journal of Archaeology Special Publication, New Zealand.

Sheppard, P.J., Walter, R. and Parker, R.J. 1997. Basalt sourcing and the development of Cook Island exchange systems. In: Weisler, M.I. (ed), Prehistoric long-distance interaction in Oceania: An interdisciplinary approach, pp. 85-110. New Zealand Archaeological Association Monograph 21, NZAA, Auckland.

Sinton, J. M. 1990. Geologic and archaeologic reference collections for south Polynesian adze studies. Hawaii Bishop Research Institute, Honolulu. 
Sinton, J.M. and Sinoto, Y.H. 1997. A geochemical database for Polynesian adze studies. In: Weisler, M.I. (ed), Prehistoric long-distance interaction in Oceania: An interdisciplinary approach, pp. 194-204. New Zealand Archaeological Association Monograph 21, NZAA, Auckland.

Sinton, J.M., Johnson, K. and Price, R. 1985. Petrology and geochemistry of volcanic rocks from the northern Melanesian borderland. In: Brocher, T. (ed), Investigations of the Northern Melanesian Borderland, pp. 35-65. Earth Science Series Vol. 3. Circum-Pacific Council for Energy and Mineral Resources, Houston.

Walter, R. 1990. The Southern Cook Islands in Eastern Polynesian Prehistory. Unpublished PhD thesis, University of Auckland.

Walter, R. and Sheppard, P.J. 1996. The Ngati Tiare adze cache: Further evidence of prehistoric contact between West Polynesia and the Southern Cook Islands. Archaeology in Oceania 31: 33-39.

Ward, G.K. and Smith, I.E. 1974. Characterization of chert sources as an aid to the identification of patterns of trade, Southeast Solomon Islands: A preliminary investigation. Mankind 9: 181-186.

Weisler, M.I. 1989. Towards documenting exchange in a complex chiefdom: An essay in method. Paper presented at the 54th Annual Meeting of the Society for American Archaeology, Atlanta, Georgia.

Weisler, M.I. 1990a. Sources and sourcing of volcanic glass in Hawai'i: Implications for exchange studies. Archaeology in Oceania 25: 16-23.

Weisler, M.I. 1990b. A technological, petrographic, and geochemical analysis of the Kapohaku adze quarry, Lana'i, Hawai' ian Islands. New Zealand Journal of Archaeology 12: 29-50.

Weisler, M.I. 1990c. Chemical characterization and sourcing of volcanic glass artifacts from Pokải Bay, O'ahu. Environmental and Energy Services Co, Honolulu.

Weisler, M.I. 1993a. Chemical characterisation and provenance of Manu'a adz material using a nondestructive X-Ray Fluorescence technique. In: Kirch, P.V. and Hunt, T.L. (eds), The To'aga Site: Three millennia of Polynesian occupation in the Manu'a Islands, American Samoa. Contribution to the University of California Archaeological Research Facility Berkeley, Number 51, pp. 167-188. Berkeley.

Weisler, M.I. 1993b. Long-distance interaction in prehistoric Polynesia: Three case studies. Unpublished PhD thesis, Department of Anthropology, University of California, Berkeley.

Weisler, M.I. 1993c. Provenance studies of Polynesian basalt adze material: A review and suggestions for improving regional data bases. Asian Perspectives 32(1): 61-83.

Weisler, M.I. 1994. The settlement of marginal Polynesia: New evidence from Henderson Island. Journal of Field Archaeology 21: 83-102.

Weisler, M.I. 1995. Henderson Island prehistory: Colonization and extinction on a remote Polynesian island. Biological Journal of the Linnean Society 56: 377-404.

Weisler, M.I. 1996a. An archaeological survey of Mangareva: Implications for regional settlement models and interaction studies. Man and Culture in Oceania 12: 61-85.

Weisler, M.I. 1996b. Taking the mystery out of the Polynesian 'mystery' islands: A case study from Mangareva and the Pitcairn Group. In: Davidson, J., Irwin, G., Leach, F., Pawley, A. and Brown, D. (eds), Pacific culture history. Essays in Honour of Roger Green, pp. 615-629. New Zealand Journal of Archaeology Special Publication, Dunedin.

Weisler, M.I. (ed) 1997a. Prehistoric long-distance interaction in Oceania: An interdisciplinary approach. New Zealand Archaeological Association Monograph 21, NZAA, Auckland.

Weisler, M.I. 1997b. Prehistoric long-distance interaction at the margins of Oceania. In: Weisler, M.I. (ed), Prehistoric long-distance interaction in Oceania: An interdisciplinary approach, pp. 149-172. New Zealand Archaeological Association Monograph 21, NZAA, Auckland.

Weisler, M.I. and Kirch, P.V. 1996. Interisland and interarchipelago transfer of stone tools in prehistoric Polynesia. Proceedings of the National Academy of Sciences, USA 93: 1381-1385.

Weisler, M.I., Kirch, P.V. and Endicott, J.M. 1994. The Mata'are basalt source: Implications for prehistoric interaction studies in the Cook Islands. Journal of the Polynesian Society 103: 203-216.

Weisler, M.I. and Sinton, J.M. 1997. Towards identifying prehistoric interaction systems in Polynesia. 
In: Weisler, M.I. (ed), Prehistoric long-distance interaction in Oceania: An interdisciplinary approach, pp. 173-193. New Zealand Archaeological Association Monograph 21, NZAA, Auckland.

Weisler, M.I. and Woodhead, J. 1995. Basalt Pb isotope analysis and the prehistoric settlement of Polynesia. Proceedings of the National Academy of Sciences, USA 92: 1881-1885.

White, A.J.R. 1987. Appendix 7. Petrography of some stone adzes from Tongatapu, Tonga group. In: Poulsen, J. (ed), Early Tongan prehistory, pp. 279-281. Terra Australis 12. Department of Prehistory, Research School of Pacific Studies. The Australian National University, Canberra.

Williams, K.L. 1987. An introduction to X-Ray Spectrometry: X-Ray Fluorescence and electron microprobe analysis. Allen and Unwin, London.

Wilson, A.L. 1978. Elemental analysis of pottery in the study of its provenance: A review. Journal of Archaeological Science 5: 219-236.

Withrow, B. 1990. Prehistoric distribution of stone adzes on Hawaii Island: Implications for the development of Hawaiian chiefdoms. Asian Perspectives 29: 235-250.

Withrow, B. 1991. Prehistoric production, distribution, and use of stone adzes: Implications for the development of Hawaiian chiefdoms. Unpublished PhD thesis, University of Minnesota, Minneapolis.

Wright, T.L. 1971. Chemistry of Kilauea and Mauna Loa lava in space and time. Geological Survey Professional Paper 735. United States Government Printing Office, Washington, D.C. 
terra australis 31 